Article

\title{
Insights into the Migration Routes and Historical Dispersion of Species Surviving the Messinian Crisis: The Case of Patella ulyssiponensis and Epizoic Rhodolith Lithophyllum hibernicum
}

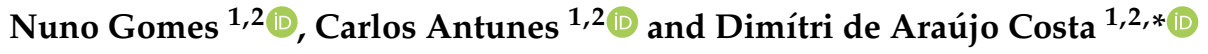 \\ 1 Interdisciplinary Centre of Marine and Environmental Research (CIIMAR), University of Porto, \\ Terminal de Cruzeiros do Porto de Leixões, Avenida General Norton de Matos, s/n, \\ 4450-208 Matosinhos, Portugal; Nuno@ciimar.up.pt (N.G.); cantunes@ciimar.up.pt (C.A.) \\ 2 Aquamuseu do Rio Minho, Parque do Castelinho, 4920-290 Vila Nova de Cerveira, Portugal \\ * Correspondence: dimitri.costa@ciimar.up.pt
}

check for updates

Citation: Gomes, N.; Antunes, C.; Costa, D.d.A. Insights into the Migration Routes and Historical Dispersion of Species Surviving the Messinian Crisis: The Case of Patella ulyssiponensis and Epizoic Rhodolith Lithophyllum hibernicum. Hydrobiology 2022, 1, 10-38. https://doi.org/ 10.3390/hydrobiology1010003

Academic Editors: Lucian Pârvulescu and Octavian Pacioglu

Received: 29 October 2021

Accepted: 17 November 2021

Published: 25 November 2021

Publisher's Note: MDPI stays neutral with regard to jurisdictional claims in published maps and institutional affiliations.

Copyright: (c) 2021 by the authors. Licensee MDPI, Basel, Switzerland. This article is an open access article distributed under the terms and conditions of the Creative Commons Attribution (CC BY) license (https:/ / creativecommons.org/licenses/by/ $4.0 /)$.

\begin{abstract}
The genus Patella (Patellogastropoda, Mollusca) is represented by a group of species exclusive to the Northeast Atlantic Ocean (including Macaronesian archipelagos) and Mediterranean Sea. The species Patella ulyssiponensis and Patella aspera are common in European waters, with the first inhabiting continental coast, and the second endemic to Macaronesian archipelagos. However, the acceptance of these two lineages as separate species is still highly debated. The red coralline species algae Lithophyllum hibernicum, distributed from Northeast Atlantic to the Mediterranean, is usually found as epilithic crusts or unattached forms (named rhodolith beds), although it also forms epizoic crusts on other organisms, e.g., shell surfaces. In order to study the historic dispersal and migration routes of the Patella ulyssiponensis-aspera complex, taxonomic, genetic and biogeographic approaches were employed based on haplotype network analyses and estimations for the most common recent ancestor (TMRCA), using Cytochrome Oxydase I. A synonymy for these two species is proposed, with the presence of a shared haplotype between the continental (P. ulyssiponensis) and insular (P. aspera) lineages, and with basis of morphological and nomenclatural data. We propose an evolutionary scenario for its dispersal based on a high haplotype diversity for the Mediterranean regions, indicating its possible survival during the Messinian Salinity Crisis (6-5.3 Mya), followed by a colonization of the Proto-Macaronesian archipelagos. The epizoic association of L. hibernicum on P. ulyssiponensis shell adult surface is recorded in this study, likewise the promotion of settlement conditions provided by these coralline algae to P. ulyssiponensis larvae, may explain the reach of P. ulyssiponensis distribution through rhodolith transportation.
\end{abstract}

Keywords: interspecific relationship; Lithophyllum hibernicum; Patella aspera; Macaronesia; Northeast Atlantic; principle of priority

\section{Introduction}

Patella Linnaeus, 1758 is a gastropod genus with 15 valid species, i.e., Patella aspera Röding, 1798, Patella caerulea Linnaeus, 1758, Patella candei d'Orbigny, 1840, Patella depressa Pennant, 1777, Patella ferruginea Gmelin, 1791, Patella gomesii Drouët, 1858, Patella lugubris Gmelin, 1791, Patella ordinaria Mabille, 1888, Patella pellucida Linnaeus, 1758, Patella rustica Linnaeus, 1758, Patella skelettensis Massier, 2009, Patella swakopmundensis Massier, 2009, Patella tenuis Gmelin, 1791, Patella ulyssiponensis Gmelin, 1791, and Patella vulgata Linnaeus, 1758 [1]. This group is characterized by "the coiling of the radula below the visceral mass and gonad" and "lack of pluricuspid cusp 1" [2].

Joseph Christiaens performed the first revision study of genus Patella, proposing the use of P. ulyssiponensis aspera for the Atlantic islands [3]. The last suggestion currently accepted was recommended by Weber and Hawkins, indicating P. ulyssiponensis for European coast shore, and P. aspera for Macaronesian archipelagos [4]. The P. ulyssiponensis-aspera 
complex is quite common in North Atlantic waters, from Norway to Mauritania, including the Macaronesian archipelagos, and in the Mediterranean, Black and Azov Seas [3,5,6], occurring on wave-exposed lower intertidal rock pools and on mid zone coralline pools $[7,8]$.

The species P. ulyssiponensis is less tolerant to desiccation than other Patella spp. [7,9], and less adapted for metabolism at high temperatures [10]. This species is a protandrous hermaphrodite with external fertilization, reaching sexual maturity around $40 \mathrm{~mm}$ in shell length, being reproductively active during the winter and early spring [11,12]. Larvae can spend from 2 to 32 days before settling on hard substrate [13]. This limpet is one of the most valuable commercially for human consumption, with Azorean stocks decreasing rapidly [14].

The species P. ulyssiponensis shows more similarity in shell morphology to congeneric individuals from the same geographical area than with individuals from the same species from different localities, pointing to a high morphological plasticity determined by environmental conditions [15].

This gastropod has a relationship with crustose coralline red algae, with an involvement of these algae for the recruitment of limpet larvae [16], serving as substratum for their settlement, that may promote survivorship in early benthic stages, with newly settled $P$. ulyssiponensis being confined to surfaces covered with crustose coralline algae for at least 3 years [17].

Red coralline algae (Corallinophycidae, Rhodophyta) have a varied range of growthforms [18,19], from epizoic, epiphytic (grow on other algae) and epilithic (on rocks) cruststype to unattached forms (i.e., rhodoliths or maërl) $[18,20,21]$. Structures formed by coralline crusts and rhodolith beds provide a wide range of ecological niches and animal or plant species associations $[22,23]$. Occurring mostly on the intertidal area, usually formed by calcified segments joined by non-calcified segments that provide flexibility [24], these seaweeds have long lifespans due to their slow growth rates [25]. The species Lithophyllum hibernicum Foslie, 1906 is common and exclusive of North Atlantic European coast, being sometimes in association with limpets, mainly on P. ulyssiponensis shell surface.

This study is centered on P. ulyssiponensis, seeking to understand and solve its taxonomic status (using morphological and genetic data), geographic variation (actual distribution and biogeographic approach), and the hypothesis of survival in the Messinian Salinity Crisis Event and colonization of the Macaronesian archipelagos. Additionally, the epizoic rhodolith-forming algae L. hibernicum is reported.

\section{Material and Methods}

\subsection{Study Area}

Samples were collected on the exposed rocky shores of the mid to lower intertidal zone from "Parque Natural do Litoral Norte" [North Littoral Natural Park], in Esposende, Portugal: Belinho Beach $\left(41^{\circ} 34^{\prime} 03.8^{\prime \prime} \mathrm{N}, 8^{\circ} 47^{\prime} 50.8^{\prime \prime} \mathrm{W}\right.$; on 17 May 2019), Rio de Moinhos Beach $\left(41^{\circ} 33^{\prime} 48^{\prime \prime} \mathrm{N}, 8^{\circ} 47^{\prime} 48^{\prime \prime} \mathrm{W}\right.$; on 18 March 2021); and specimens from Âncora Beach ( $41^{\circ} 49^{\prime} 39^{\prime \prime}$ N; $8^{\circ} 52^{\prime} 27^{\prime \prime}$ W; on 15 March 2021), close to Minho River estuary zone (Figures 1 and 2). 

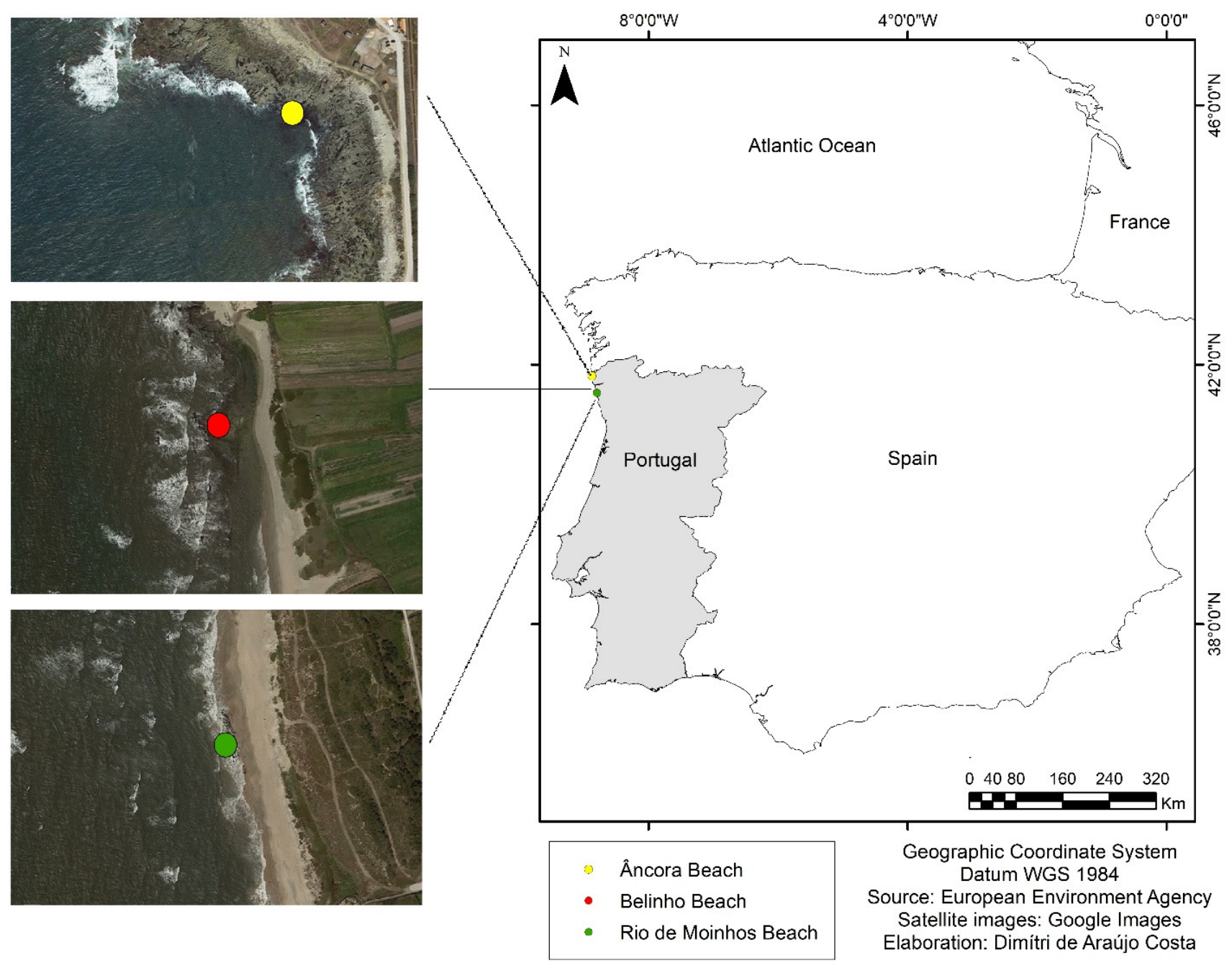

Figure 1. Study area, located on the North region of the Portuguese coast, Iberian Peninsula. Âncora Beach (yellow point), Belinho Beach (red), Rio de Moinhos (green).

\subsection{Data Collection}

Samples were collected using spatulas (to remove the limpets from the rocks, Figure 2) and stored in thermal boxes with ice. In the laboratory, photographs of the organisms were taken using a Nikon Digital Sight D5-L1 camera and a stereomicroscope Nikon SMZ800 (Figures 3-7). Specimens were deposited at the Natural History Museum of the Iberian Peninsula (NatMIP-“Museu de História Natural da Península Ibérica”), Aquamuseu do Rio Minho, Vila Nova de Cerveira, Portugal.

\subsection{Data Analyses}

DNA samples were extracted from the foot of P. ulyssiponensis using an E.Z.N.A. Mollusc DNA Kit (Omega Bio-tek). Amplification of the mitochondrial gene cytochrome $c$ oxidase I (COI-5P), was performed using the primer pairs LoboF1 and LoboR1 [26]. PCR (Polymerase Chain Reaction) reactions contained $21 \mu \mathrm{L}$ of VWR Red Taq DNA Polymerase Master Mix, $1 \mu \mathrm{L}$ of each primer $(10 \mathrm{mM})$ and $2 \mu \mathrm{L}$ of DNA template. The PCR cycling conditions used were: $1 \mathrm{~min}$ at $94{ }^{\circ} \mathrm{C} ; 5$ cycles of $30 \mathrm{~s}$ at $94{ }^{\circ} \mathrm{C}, 1.5 \mathrm{~min}$ at $45^{\circ} \mathrm{C}, 1 \mathrm{~min}$ at $72{ }^{\circ} \mathrm{C} ; 35$ cycles of $30 \mathrm{~s}$ at $94{ }^{\circ} \mathrm{C}, 1.5 \mathrm{~min}$ at $52{ }^{\circ} \mathrm{C}$, and $1 \mathrm{~min}$ at $72{ }^{\circ} \mathrm{C} ; 5 \mathrm{~min}$ at $72{ }^{\circ} \mathrm{C}$. PCR products were visualized in a $1 \%$ agarose gel and purified using ExoSap at $37^{\circ} \mathrm{C}$ for $15 \mathrm{~min}$, followed by $15 \mathrm{~min}$ at $80^{\circ} \mathrm{C}$. These analyses above were conducted in the Interdisciplinary Centre of Marine and Environmental Research (CIIMAR), University of Porto, Portugal. 


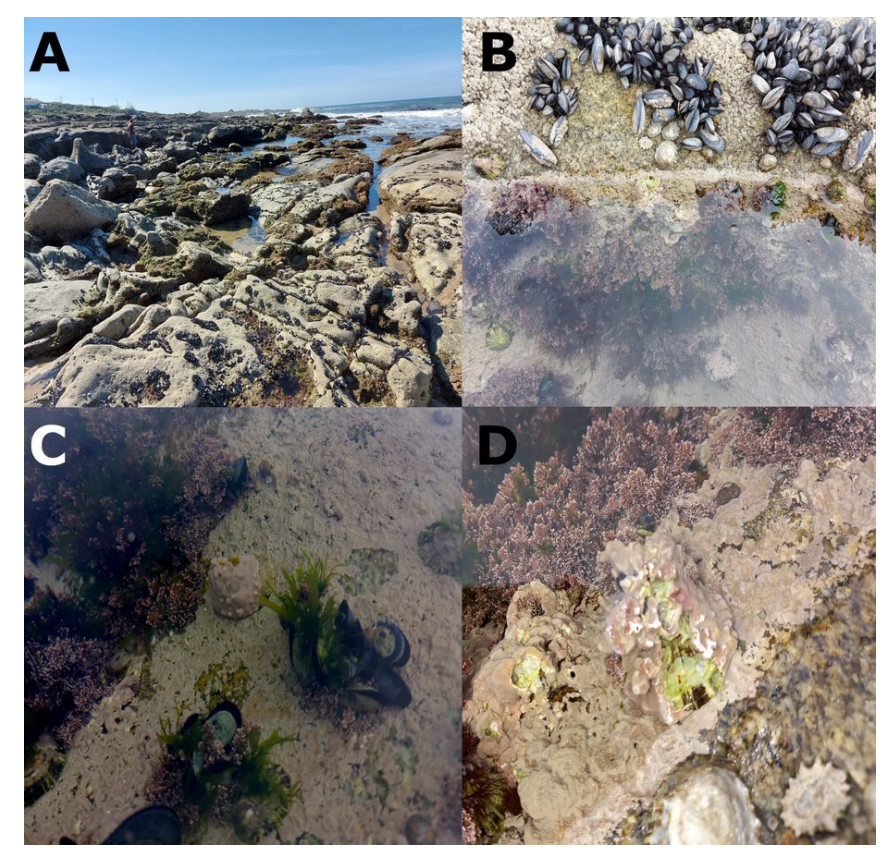

Figure 2. Âncora Beach intertidal overview (A); Rock pool overview (B); Patella ulyssiponensis on rockpool covered with Lithophyllum hibernicum (C); and highlight of rhodolith algae on limpet surface (D).

COI-5P sequences were edited and aligned using MEGA software [27] and verified for the presence of stop codons, insertions or deletions. Homology searches were performed in the BOLD database [28] and with BLAST [29] in the GenBank database [30]. Phylogenetic analyses for the Patella ulyssiponensis-aspera complex were carried using a dataset composed by the single sequence obtained in this study (OK465193 GenBank accession number) and 271 public sequences of Patella ulyssiponensis and Patella aspera (Table S1). The software JModelTest [31] was used to find the best-fit model for nucleotide substitutions, being this model Hasegawa-Kishino-Yano (HKY) with Gamma distributions. Maximum Likelihood (ML) tree was constructed with MEGA software using HKY model with Gamma distribution. Bootstraps were performed using 10,000 replicates. Bayesian Inference analyses were performed with Mr. Bayes software [32] using the General Time Reversible substitution model (GTR) with Gamma distribution, running for 35 million generations sampled every 1000 generations, using two chains with a temperature setting of 0.1 . After confirming that the average standard deviation of the split frequencies was $<0.01$, the first $25 \%$ of the trees were discarded as burn-in and the remaining were used to construct a majorityrule consensus tree. Pairwise distances were calculated using the Kimura 2-parameter model. Haplotype genealogy analyses was performed using TCS software [33] with a 95\% statistical parsimony connection limit using 226 P. ulyssiponensis and P. aspera sequences, with 46 sequences being removed from the original dataset due to lack of precise geographical location data. The final dataset, used only for haplotype genealogy analyses, was trimmed to a final size of 376 base pairs due to lack of resolution on the opening and closing segments of some sequences. Genetic differentiation among populations (European Atlantic continental, Mediterranean, Morocco, Azores and Madeira plus Canary sub-group) was calculated using an analysis of molecular variation (AMOVA) in GenAlEx [34]. FST Haplotype $(\mathrm{Hd})$ and nucleotide $(\pi)$ diversity and Tajima's D and Fu's FS neutrality tests were performed using Arlequin 3.5 [35] for the populations mentioned above and for each Mediterranean population (Alboran, Balearic, Tyrrhenian, Ionian and Aegean).

The analyses between Atlantic Patella species were carried out by the construction of a Maximum Likelihood tree using a HKY + G substitution model, conducted with 10,000 bootstraps on MEGA software, from a dataset composed by 418 sequences of $P$. candei, P. lugubris, P. caerulea, P. pellucida, P. depressa, P. ferruginea, P. vulgata, P. rustica, 
P. ulyssiponensis and P. aspera. Public sequences used for tree construction available on Table S1.

The software BEAST v.1.7 [36] was used to estimate the most recent common ancestor (TMRCA) from a dataset consisting of one sequence of Eoacmaea profunda as the basal group, one sequence from one species for the genus Helcion, Cymbula and Scutellastra and one sequence of each species of Patella, except for Patella ulyssiponensis in which were used one sequence representing the continental basal haplotype, one sequence for the Azores archipelagos basal haplotype and one sequence from the most represented shared haplotype from Madeira and Canary archipelagos. The choice of these sequences was made in order to use the Yule speciation model obtaining a bifurcating pattern, chosen due to the usage of extant only lineages. The evolutionary model chosen was the HKY model with a proportion of invariable sites and four Gamma categories $(\mathrm{HKY}+\mathrm{I}+\mathrm{G})$ chosen by JModelTest. The fossil calibration was performed by rooting the age of the clade containing the sister group of Patella using sequences of Scutellastra exusta, Helcion concolor and Cymbula safiana. This calibration was done through the oldest known fossil record of this paraphyletic group, "Patella" soyaensis Kase and Shigeta, 1996 from the Upper Cretaceous (75 Mya) of northern Japan, assigned to Scutellastra by Ridgway et al. [2]. A relaxed clock model was used with a lognormal distribution and a substitution rate of $1.2 \pm 0.1 \%$ (s.d.) per million years, based on values for other Molluscs [37]. The analyses were performed by 20 million chains, sampling each 1000 generations with the initial $25 \%$ being discarded as burn-in. The software TRACER 1.5 [38] was used to check the effective size sample for each parameter (at least higher than 100), as well as for checking the confidence intervals for each TMRCA obtained from the 95\% highest posterior densities interval. The software FigTree 1.4 was used to obtain the tree visualization.

\subsection{Geological Maps}

Ancient satellite Earth images (i.e., Upper Cretaceous, Lower Miocene, Messinian stage, and Lower Pliocene) were obtained by the GPlates software, version 2.2.0 [39]. Information of ocean currents old periods was obtained through Britannica website [40].

\section{Results}

\subsection{Biogeography Patterns and Genetic Analyses}

Trees obtained with Maximum Likelihood and Bayesian Inference shared a similar topology with a separation of two different lineages, one from the Northeast Atlantic and Mediterranean continental shelf and another from the Macaronesian archipelagos with some Mediterranean populations (Figure 8 and Figure S1). On ML tree, bootstrap support values for the insular and continental clades are $<70$ ( 35 for the continental and 65 for the insular clades) (Figure S1); nonetheless, Bayesian support values of these same clades are of 100 (Figure S2). Within lineages, genetic distance was $0.5 \pm 0.1 \%$ (s.e.) for the continental lineage and $0.7 \pm 0.2 \%$ (s.e.) for the insular lineage. The distance between the two lineages was $3.5 \pm 0.9 \%$ (s.e.). The specimen sequenced nested within the continental grade, being most similar to a specimen sampled in Asturias (North Spain). Interspecific distances range between $7 \%$ and $16 \%$, with exception of the case between P. lugubris and P. candei which had an interspecific distance of $4 \%$ (Figure 9). Haplotype genealogy revealed 85 different haplotypes, 15 unique for the Macaronesian region, 69 for the continental region and one shared between the Mediterranean, Madeira, Tenerife and Fuerteventura. Of those 69 haplotypes, five are exclusive to the Iberian Atlantic, six shared between Atlantic and Mediterranean, two exclusives to Morocco, plus one shared with Atlantic and Mediterranean populations, with the remaining being exclusive to the Mediterranean. Of the last ones, 36 are unique to Italy, four to Greece, two to Portugal, seven in the Spanish Mediterranean region, three for the Spanish region of Asturias and four for the French Mediterranean (Figures 10 and 11, Table S2). According to AMOVA, 60\% of the molecular variance was found between populations and $40 \%$ within populations. 
Haplotype (Hd) and nucleotide $(\pi)$ diversity and Tajima's D and Fu's FS neutrality tests for all regions are available in Table 1, and values for the Mediterranean regions are available in Table 2. $\mathrm{F}_{\mathrm{ST}}$ values show little differentiation between Atlantic and Mediterranean populations $\left(\mathrm{F}_{\mathrm{ST}}=0.04\right)$ and high differentiation between Continental and Insular populations (Table 3). Analyses of each Mediterranean population $\mathrm{F}_{\mathrm{ST}}$ values shows little differentiation, except for the Alboran Sea populations, which seem to have a moderate differentiation in structure comparing with the remaining Mediterranean regions (Table 4). Populations from the Balearic, Tyrrhenian and Ionian Seas seem to have gone through a recent demographic expansion, while the Alboran and Aegean Seas populations seem to be demographically stable (Table 2). Estimated TMRCA values and corresponding confidence intervals are available on Table 5.

Table 1. Number of sequences ( $\mathrm{N}^{\circ}$ Seq.), haplotypes (Hap.), haplotype diversity (Hd) and standard deviation (SD), nucleotide diversity $(\Pi)$ and SD, and Tajima's D and Fu's FS neutrality tests $\left({ }^{*} p<0.05 ;{ }^{* *} p<0.01\right)$ per region.

\begin{tabular}{ccccccc}
\hline Population & $\mathbf{N}^{\circ}$ Seq. & Hap. & Hd & I & Tajima's D & Fu's FS \\
\hline Atlantic Continental & 94 & 17 & $0.7868 \pm 0.0356$ & $0.003691 \pm 0.002537$ & $-1.9445^{* *}$ & $-10.5684^{* *}$ \\
Mediterranean & 117 & 63 & $0.9524 \pm 0.0117$ & $0.009806 \pm 0.005530$ & $-1.8685^{* *}$ & $-26.0188^{* *}$ \\
Morocco & 14 & 3 & $0.4835 \pm 0.1425$ & $0.002806 \pm 0.002217$ & -0.5313 & 0.9689 \\
Azores & 14 & 9 & $0.8791 \pm 0.0788$ & $0.005465 \pm 0.003655$ & $-1.5999^{*}$ & $-4.7175^{* *}$ \\
Madeira/Canarias & 17 & 7 & $0.7500 \pm 0.0924$ & $0.004380 \pm 0.003035$ & -0.7066 & $-2.1779 *$ \\
\hline
\end{tabular}

Table 2. Number of sequences, haplotypes, haplotype diversity and SD, nucleotide diversity ( $\Pi$ ) and SD, and Tajima's D and Fu's FS neutrality tests $\left.{ }^{* *} p<0.01\right)$ per Mediterranean sub-region.

\begin{tabular}{cccccccc}
\hline Population & $\mathbf{N}^{\circ}$ Seq. & Hap. & Hd & П & Tajima's D & Fu's FS \\
\hline Alboran & 15 & 4 & $0.4667 \pm 0.1478$ & $0.002128 \pm 0.001822$ & -0.39 & -0.82 \\
Balearic & 23 & 12 & $0.8933 \pm 0.0495$ & $0.007148 \pm 0.004401$ & $-1.75^{* *}$ & $-5.01^{* *}$ \\
Tyrrhenian & 54 & 34 & $0.9399 \pm 0.0214$ & $0.009477 \pm 0.005427$ & $-1.73^{* *}$ & $-26.09 * *$ \\
Ionian & 15 & 15 & $1.0000 \pm 0.0243$ & $0.010790 \pm 0.006393$ & -1.24 & $-13.69^{* *}$ \\
Aegean & 5 & 5 & $1.0000 \pm 0.1265$ & $0.012766 \pm 0.00876$ & -0.65 & -1.41 \\
\hline
\end{tabular}

Table 3. $\mathrm{F}_{\mathrm{ST}}$ values for Patella ulyssiponensis populations $\left({ }^{*} p\right.$ value $<0.05$; ${ }^{* *} p$ value $\left.<0.01\right)$.

\begin{tabular}{|c|c|c|c|c|c|}
\hline & Atlantic & Mediterranean & Morroco & Azores & Canary + Madeira \\
\hline \multicolumn{6}{|l|}{ Atlantic } \\
\hline Mediterranean & $0.04^{* *}$ & & & & \\
\hline Morocco & $0.25^{* *}$ & $0.12 *$ & & & \\
\hline Azores & $0.88^{* *}$ & $0.88^{* *}$ & $0.73 * *$ & & \\
\hline Canary+Madeira & $0.89 * *$ & $0.90 * *$ & $0.74 * *$ & $0.40 * *$ & \\
\hline
\end{tabular}

Table 4. $\mathrm{F}_{\mathrm{ST}}$ values for Patella ulyssiponensis Mediterranean sub-populations (** $p$ value $\left.<0.01\right)$.

\begin{tabular}{cccccc}
\hline & Alboran & Balearic & Tyrrhenian & Ionian & Aegean \\
\hline Alboran & & & & & \\
Balearic & $0.21^{* *}$ & & & & \\
Tyrrhenian & $0.17^{* *}$ & $0.05^{* *}$ & & & \\
Ionian & $0.23^{* *}$ & 0.03 & 0.06 & & \\
Aegean & $0.40^{* *}$ & $0.09^{* *}$ & 0.08 & -0.02 & \\
\hline
\end{tabular}


Table 5. Estimates of TMRCA and corresponding confidence intervals (CI) (values in million years Mya).

\begin{tabular}{ccc}
\hline Clade & TMRCA & CI \\
\hline Patellidae & 96.6 & $64.7-143$ \\
Patella & 36.1 & $13.6-67.6$ \\
P. vulgata + P. ulyssiponensis & 18.0 & $6.3-33.2$ \\
P. ulyssiponensis (continental and insular lineages) & 5.3 & $1.2-12$ \\
P. ulyssiponensis (Azores and Tenerife) & 1.2 & $0.1-3.15$ \\
\hline
\end{tabular}

\subsection{Taxonomic Account}

Kingdom Animalia Linnaeus, 1758

Phylum Mollusca Cuvier, 1797

Class Gastropoda Cuvier, 1795

SubClass Patellogastropoda Lindberg, 1986

SuperFamily Patelloidea Rafinesque, 1815

Family Patellidae Rafinesque, 1815

Genus Patella Linnaeus, 1758

Patella ulyssiponensis Gmelin, 1791

Patella ulyssiponensis Gmelin, 1791: 3706 (based on pl. 2, Fig. G2 by De Favanne de Montcervelle, 1780) [41]; Dillwyn, 1817: 1031 [42]; Blainville, 1825: 117 [43]; Christiaens, 1973: 1329-1332, pl. I (1, 2, 3), Fig. 6 [3]; Christiaens, 1974: 65 [44]; Ortea, 1980: 66-68, Fig. 5 [45]; Titselaar, 1998: 52-58, pl. 3, Figs. 1-4, pl. 4, Figs. 1-14 [46]; Öztürk \& Ergen, 1999: 516, Fig. 5 [47]; Callapez and Soares, 2000: 314, Fig. 2, pl. 2, Fig. 17 [48]; Bouchet et al., 2001: 182 [49]; Ávila et al., 2002: 348, Fig. 32 [50]; Cabral, 2003: Figs. 3,5 [51]; Cabral and Silva, 2003: Figs. 3b,4b [52]; Cabral, 2007: Fig. 1 [53]; Hodgson et al., 2007: Fig. 2 [54]; Dhora, 2009: 540 [55]; Sanna et al., 2012: Fig. 4b(1,3,5) [15]; Ivanov and Fateryga, 2015: 44 [56]; Borges et al., 2016: Fig. 1a [57]; Titselaar, 2019: Fig. 15 [58]; Vasconcelos et al., 2019: Figs. 1, 5, and 6b, Tabs. 1,3 [12]; Crocetta et al., 2020: Tabs. 2,4 [59].

Patella aspera Röding, 1798: 10 (based on pl. 2, Fig. G2 by De Favanne de Montcervelle, 1780) [60]; Lamarck, 1819: 327 [61]; Blainville, 1825: 108 [43]; Reeve, 1855: 140, pl. 11, Fig. 23a,b [62]; Servain, 1886: 44 [63]; Simroth, 1888: 215 [64]; Watson, 1897: 299 [65]; Nobre, 1930: 60 [66]; Mermod, 1950: 691, Fig. 2 [67]; Evans, 1953: 357 [68]; Evans, 1958: 131-136 [69]; Fischer-Piette and Gaillard, 1959: 145-147, 193-194, Figs. 2q-t, 3e, 8, and 14 [70]; Kolstad, 1959: 1886-1887 [71]; Morton, 1967: 30 [72]; McMillan, 1968: 25, pl. 1, Figs. 1,3-4 [73]; Nordsieck, 1968: 14 [74]; Powell, 1973: 82, pl. 63, Fig. 4, pl. 68, Figs. 3,4 [75]; Cuerda and Galiana, 1976: 117 [76]; Nordsieck and García-Talavera, 1979: 45, pl. 6, Fig. 22 [77]; Gaffney, 1980: 566 [78]; Bowman, 1981: 652-655, Figs. 2b, 3b,d,e, and 4a-c [17]; Van Aartsen et al., 1984: 8 [79]; Campbell, 1985: 144-145 [80]; Backeljau, 1986: 9 [81]; Bosch and Moreno, 1986: 132, 134, Fig. 3b [82]; Cervella et al., 1988: Fig. 1a [83]; Graham, 1988: 80, Fig. 21 [84]; Lindner, 1989: 116, pl. 3, Fig. 2 [85]; Bellomo, 1993: Tab. 1 [86]; Weber, 1997: Fig. 275 [87]; Nakano and Ozawa, 2007: Fig. 83, Tab. 1 [88]; Santos et al., 2010: 5-6 [89]; Borges et al., 2016: Fig. 1b [57]; Castejón et al., 2021: Fig. 2 [90].

Patella athletica Bean, 1844: 264, Fig. 101 [91]; Forbes and Hanley, 1853: 425, pl. 61, Figs. 7,8 [92]; Servain, 1886: 47 [63]; Dautzenberg, 1887: 13 [93]; Nobre, 1937: 491 [94]; Evans, 1947: 412-416, 418, Fig. 1 [95]; Lucas, 1954: 38-39 [96]; Nordsieck and GarcíaTalavera, 1979: 44-45, pl. 6, Fig. 20 [77]; Nordsieck, 1982: 9 [97]; Graham, 1988: 80 [84].

Patella aurantia Gmelin, 1791: 3703 [41].

Patella azorica Jay, 1852: 100 [98].

Patella baudonii Drouët, 1858: 41, pl. 2, Figs. 8,9 [99].

Patella bonnardii Payraudeau, 1826: 89-90, pl. 3, Figs. 9-11 [100].

Patella caerulea var. tenuistriata Weinkauff, 1880: 38 [101].

Patella donacina Anton, 1838: 26 [102].

Patella listeri Di Monterosato, 1888: 165 [103]. 
Patella lowei D'Orbigny, 1840: 97-98, pl. 7, Figs. 9,10 [104]; Lecointre et al., 1967: 331,337 [105]; Nordsieck and García-Talavera, 1979: 44, pl. 5, Fig. 18 [77].

Patella paulinoi Locard, 1894: 131-132 [106].

Patella pontica Di Monterosato, 1888: 165 [103]; Milachewitch, 1916: 4-9, pl. 1, Figs. $1-3$, pl. 11, Figs. 4,5 [107].

Patella repanda Gmelin, 1791: 3707 [41].

Patella spectabilis Dunker, 1853: 39-40, pl. 6 Figs. 7-9 [108]; Nordsieck and GarcíaTalavera, 1979: 40, pl. 2, Fig. 8 [77].

Patella spinulosa Mörch, 1852: 141 [109] (Meuschen, 1787: 244 (non-binominal work) [110]).

Patella tarentina Salis Marschlins, 1793: 359, pl. 6, Fig. 2 [111]; De Lamarck, 1819: 332 [61]; Blainville, 1825: 110 [43]; Delessert, 1841: pl. 23, Fig. 7 [112]; Servain, 1886: 37 [63]; Nordsieck, 1975: 5 [113]; Nordsieck \& García-Talavera, 1979: 43, pl. 4, Fig. 14 [77]; Nordsieck, 1982: 11 [97]; Bosch and Moreno, 1986: 134, Fig. 3c [82]; Dhora, 2009: 540 [55].

Patella teneriffae Mabille, 1888: 80 [114]; Locard, 1898: 89, pl. 5, Figs. 7-9 [115]; Nordsieck, 1975: 3 [113]; Nordsieck and García-Talavera, 1979: 41-42, pl. 3, Fig. 10 [77]; Nordsieck, 1982: 10 [97].

Patella ulyssiponensis var. aspera Christiaens, 1973: 1331 [3]; Nordsieck and GarcíaTalavera, 1979: 43-44, pl. 5, Fig. 17 [77]; Ortea, 1980: 67 [45]; Poppe and Goto, 1991: 71 [116]; Corte-Real et al., 1992: 58-59, Fig. 4 [117].

Patella ulyssiponensis var. athletica Christiaens, 1973: 1331 [3]; Ortea, 1980: 66 [45].

Patella ulyssiponensis var. aurantia Ortea, 1980: 67 [45].

Patella ulyssiponensis var. baudonii Ortea, 1980: 67 [45].

Patella ulyssiponensis var. bonnardii Christiaens, 1973: 1331 [3]; Ortea, 1980: 66 [45]; Poppe and Goto, 1991: 71 [116].

Patella ulyssiponensis var. caerulea Ortea, 1980: 67 [45].

Patella ulyssiponensis var. deserta Christiaens, 1973: 1331 [3]; Ortea, 1980: 67 [45].

Patella ulyssiponensis var. lowei: Ortea, 1980: 67 [45].

Patella ulyssiponensis var. major Mörch, 1852: 141 [109].

Patella ulyssiponensis var. pontica Christiaens, 1973: 1331 [3].

Patella vulgata var. albula De Gregorio, 1884: 123 [118].

Patella vulgata var. cimbulata De Gregorio, 1884: 123 [118].

Patella vulgata var. comina De Gregorio, 1884: 122 [118].

Patella vulgata var. depressaspera De Gregorio, 1884: 122 [118].

Type material. Neotype. NNM (National Nordic Museum), nr. RMNH (Rijksmuseum van Natuurlijke Historie) 59070, designated by Titselaar [46].

Type locality. "Ulyssiponem" [41], actual Lisbon, Portugal [3].

Material Examined. Portuguese samples from Parque Natural do Litoral Norte, Esposende: (a) Belinho Beach, one adult, 32.0, 25.0, 11.0 mm (NatMIP-MGPa-0001), nine juveniles (eight complete specimens, and one with only shell structure), 6.0-11.0, 4.0-7.0, 1.5-3.0 mm (NatMIP-MGPa-0002), (b) Rio de Moinhos Beach, four adults, 26.0-30.0, 11.0-17.0, 8.0-11.0 mm (NatMIP-RFCo-0003); and from (c) Caminha, Vila Praia de Âncora Beach, one adult, 35.0, 28.5, $17.0 \mathrm{~mm}$, (NatMIP-RFCo-0004), one juvenile, 8.9, 5.9, $1.9 \mathrm{~mm}$ (NatMIP-RFCo-0005).

Diagnosis [5,84,119]: Top of shell (apex) located anteriorly to the middle (Figure 3A); radiating ridges varying at single and triple ones (Figure $3 \mathrm{~B}$ ). Tubercles arranged over the entire surface of the shell, in rows up to the apex (Figure 3A). Black strips lines on surface from apex to basis. Border shell uniformly crenulate (Figure $3 \mathrm{~A}, \mathrm{~B}$ ). Posterior margin (with lateral expansions) larger than anterior one (Figure 3A,B). Internal shell region basally whitish with black bands (thinner in both ends), medially to upper yellowgreenish, to orangey apically (Figure 3B). Radula with three unequal teeth: left tooth, with two protrusions (being one like a vestigial fourth tooth), and basally larger than central one. Yellowish to dark grey anterior cephalic tentacles basally inflated, anteriorly tapered (Figure 4A,B). Body surface with a dark grey colour pattern (Figure 3C). Pallial tentacles of mantle skirt whitish to translucent, organized in two series of distinct sizes 
(Figure 3D), may contain adhering eggs (Figure 4C). Uniformly yellow to orange foot with cream coloured edge (Figures $4 \mathrm{D}$ and $6 \mathrm{C}$ ).

Features in juvenile specimens. Juvenile individuals present slight distinctive morphological characteristics in relation to adult limpets: in individuals smaller than $3 \mathrm{~mm}$, width of coloured and uncoloured strips are a uniform standard; in larger ones, dark ridges are broader, projecting somewhat beyond the shell perimeter. This change is related to the emergence and growth of the tentacles of the mantle (for details see [17]). These juvenile limpets may be found in pools, on red crustose algae (Figure 5A,C), close to Corallina sp. and Mytilus sp. beds, as well as on adult shells surface. Young specimens have greyish feet, and as they grow, feed on red algae, then their feet start to take on an orange colour, typical of adults. Finally, mantle tentacles have a calcareous-type constitution.

Remarks. The first description for P. ulyssiponensis was performed by Lewis Dillwyn: "shell sub-oval, depressed, thin, with nine broad rays, and striated and slightly ribbed longitudinally; margin denticulated" [42]. Two years later, Jean-Baptiste De Lamarck made the first description for P. aspera: "P. testâ ovato-rotundatâ, convexiusculâ, albido-rufescente; costis radiantibus, inaequalibus, creberrimis, ultrà marginem prominulis, dorso asperis; intus margaritaceâ; vertice obtuso", meaning 'Ovate-rounded shell, convex, whitish-reddish; radiated ribs, unequal, ribbed, prominent posterior margins, coarse dorsum; internally pearly; obtuse apex' [61].

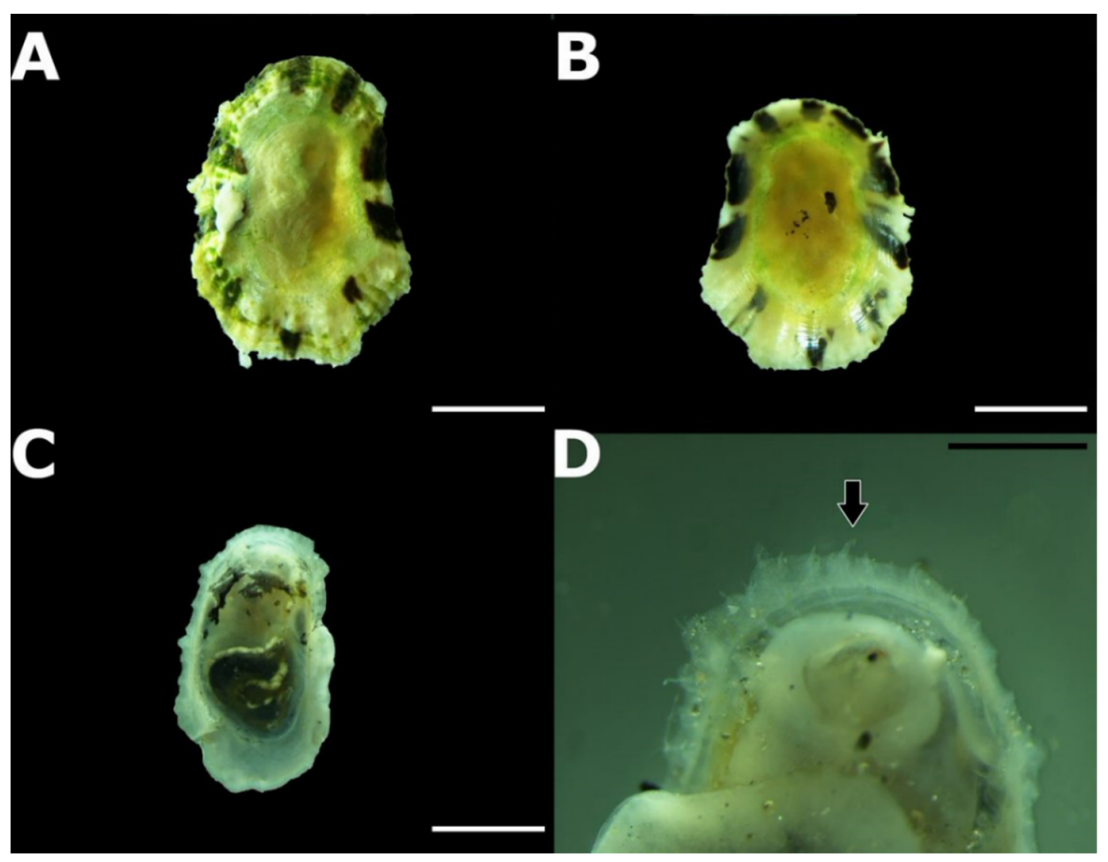

Figure 3. Patella ulyssiponensis juvenile from Belinho Beach (NatMIP-MGPa-0002): Shell dorsal view (A); Shell ventral view (B); Dorsal view of limpet, without shell, with emphasis on the digestive system (C); Detail of anterior zone of ventral view, highlighting (by arrow) the paleal tentacles (D). Scales: (A-D): $0.5 \mathrm{~cm}$. 


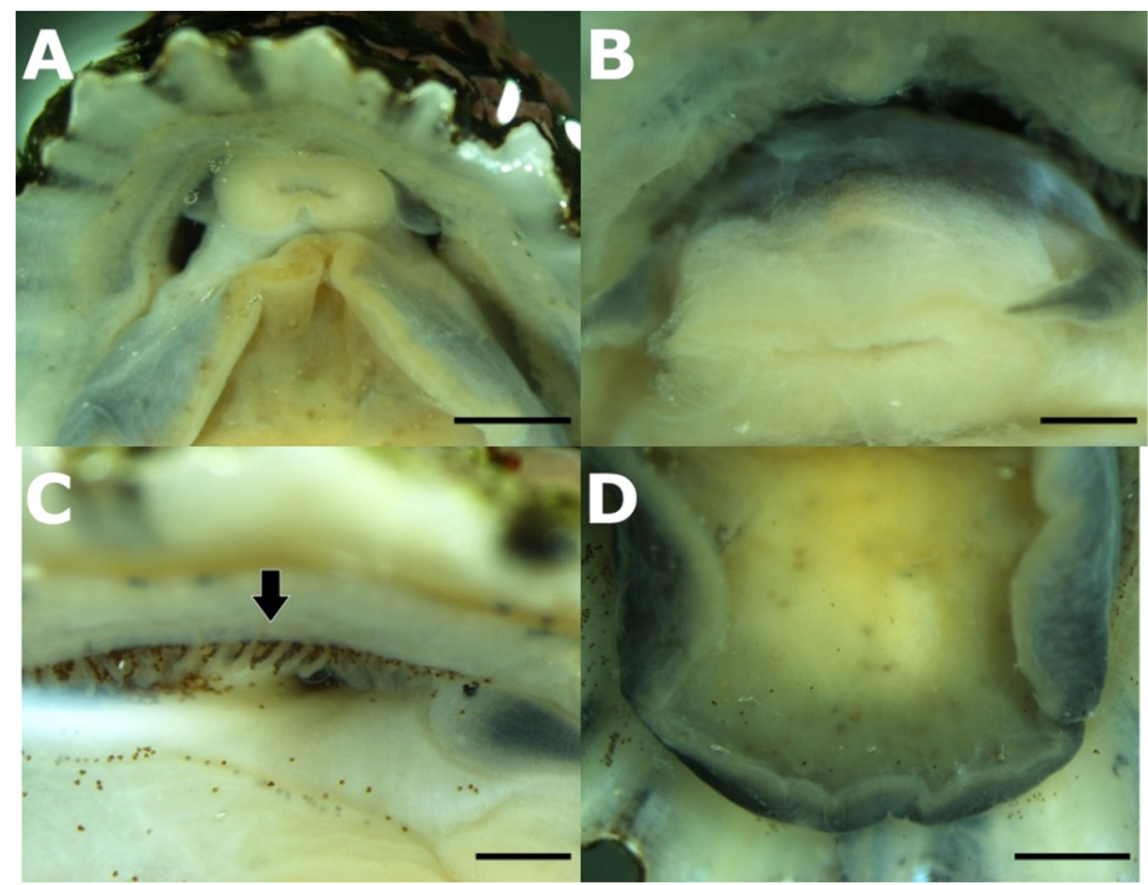

Figure 4. Patella ulyssiponensis (ventral view) from Âncora Beach (NatMIP-RFCo-0004): Anterior end (A); Head, including cephalic tentacles (B); Mantle margin, showing eggs attached on pallial tentacles (C); Posterior end, ventral and marginal dorsal view of foot (D). Scales: (A,D): $0.5 \mathrm{~cm}$; (B,C): $1 \mathrm{~mm}$.

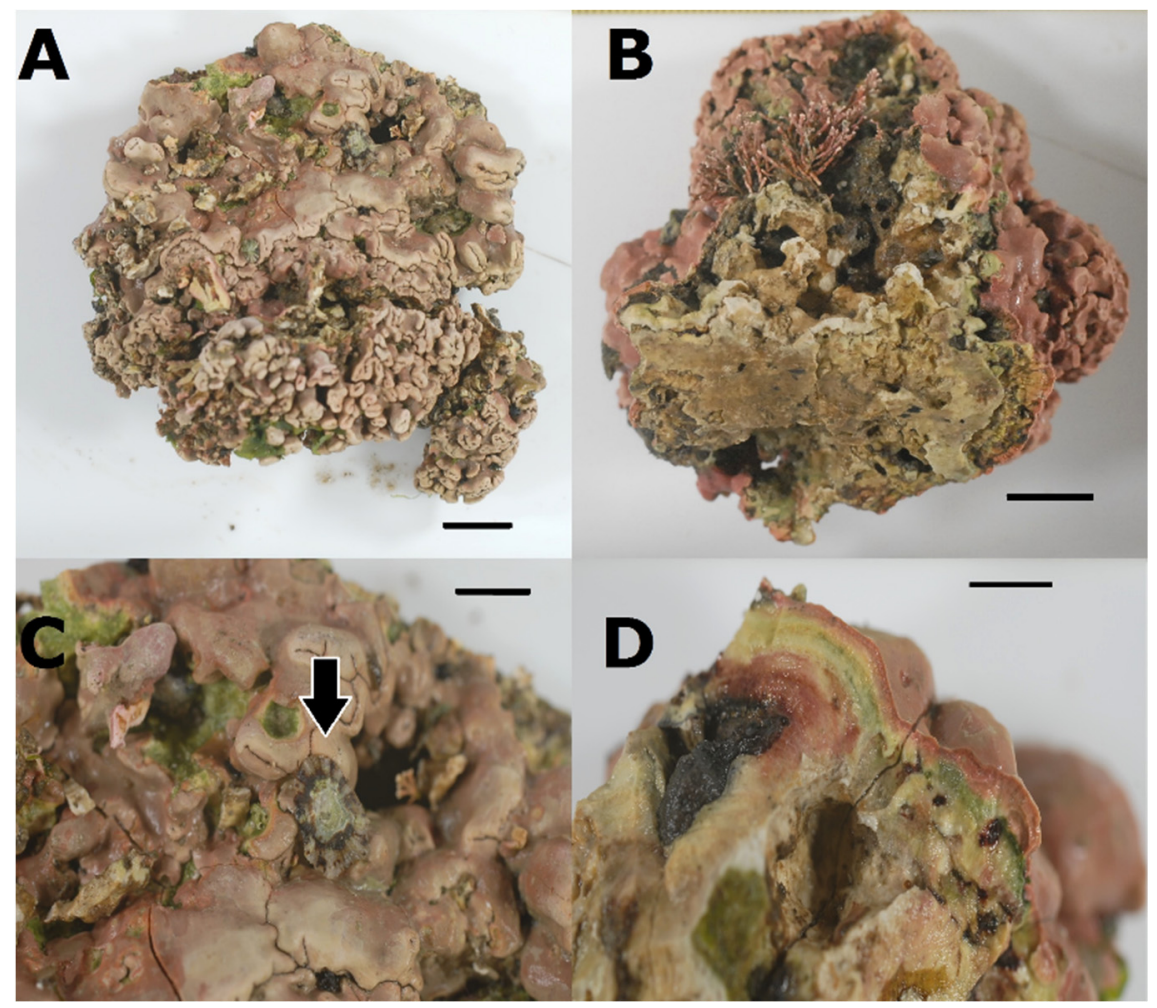

Figure 5. Lithophyllum hibernicum from Belinho Beach (NatMIP-RFCo-0002): rhodolith overview, dorsal (A), Ventral, showing the fixation zone (B); Patella ulyssiponensis juvenile between the rhodolith nodules (C); Rhodolith internal growth rings (D). Scales: $(\mathbf{A}, \mathbf{B}, \mathbf{D}): 1 \mathrm{~cm} ;(\mathbf{C}): 0.5 \mathrm{~cm}$. 


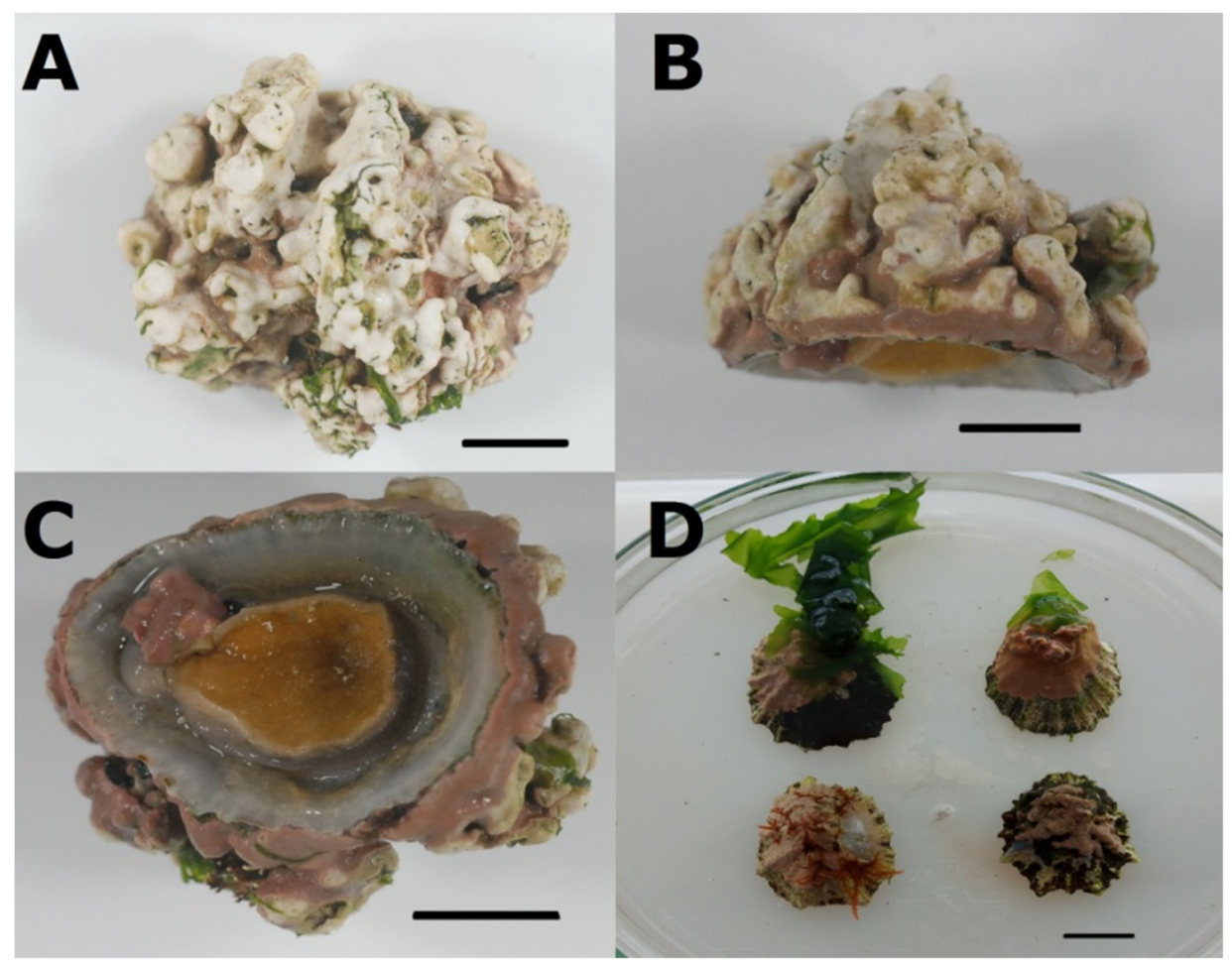

Figure 6. Lithophyllum hibernicum (NatMIP-RFCo-0001) associated with Patella ulyssiponensis (NatMIP-MGPa-0001): from Belinho Beach: Dorsal view (A); Side view (B); Ventral view (C). From Rio de Moinhos Beach (NatMIP-RFCo-0003): Dorsal view (D). Scales: (A-D): $1 \mathrm{~cm}$.

Geographical distribution. Northeast Atlantic Ocean (from Norway, United Kingdom, France, Spain, Portugal, Morocco to Mauretania), Mediterranean Sea, Aegean Sea, Marmara Sea, Black Sea and Sea of Azov [3,5,6,46].

Ecological notes. They are found on open rocky shores at the Mean Low Water of Neap Tides (MLWNT) intertidal zone and below, in crevices, rock pools and other patchy habitats with low salinities [5]. Close to other organisms, e.g., red calcareous Corallina spp. and green fleshy Ulva sp., as well as with molluscs Mytilus sp. Steromphala sp. and Gibbula sp., and cnidarians Actinia sp. populations. Additionally, this patellid has been found with another limpet, named Siphonaria pectinata [16].

Kingdom Plantae Haeckel, 1866

SubKingdom Biliphyta Cavalier-Smith, 1981

Phylum Rhodophyta Wettstein, 1901

Subphylum Eurhodophytina Saunders \& Hommersand, 2004

Class Florideophyceae Cronquist, 1960

Subclass Corallinophycidae Le Gall \& Saunders, 2007

Order Corallinales Silva \& Johansen, 1986

Family Lithophyllaceae Athanasiadis, 2016

Genus Lithophyllum Philippi, 1837

Lithophyllum hibernicum Foslie, 1906

Lithophyllum hibernicum Foslie, 1906: 24 [120]; Printz, 1929: pl. 63: Figs. 11-13 [121]; Adey and Lebednik, 1967: 44 [122]; Woelkerling, 1993: 118 [123]; Irvine and Chamberlain, 1994: 74-75 [124]; Woelkerling et al., 2005: 191 [125]; Hall-Spencer et al., 2010: Tab. 2 [126]; Guiry, 2012: 49 [127]; Hernandez-Kantun et al., 2015: 797-799, Figs. 6A,7 [128]; Gallardo et al., 2016: 18 [129]; Lugilde et al., 2016: 5 [130]; Vázquez-Ferreira and Peña, 2016: Figs. 1-10 [131]; Cormaci et al., 2017: 244-246 [132]; Hernandez-Kantun et al., 2017: 267 [133]; Pardo et al., 2017: 7, Fig. 4o-q [134]; Burel et al., 2019: 9 [135]; Athanasiadis, 2020: 69-74, Figs. 1, 2, and 3a [136]. 
Lithothamnion fasciculatum f. subtilis Foslie, 1897: 8 [137] (revised by Foslie, 1906: 24 [120]); Foslie, 1900: 31 [138].

Type. Lectotype: TRH (Norwegian University of Science and Technology) A23-1399, designated by Hernandez-Kantun et al. [128].

Type locality. Fahy Bay, Ballynakill Harbour, Galway, Ireland [120,127].

Material Examined. Tissue samples on surface of adults P. ulyssiponensis shells from Parque Natural do Litoral Norte, Esposende: (a) Belinho Beach (NatMIP-RFCo-0001, 0002), (b) Rio de Moinhos Beach (NatMIP-RFCo-0003); and from (c) Caminha, Vila Praia de Âncora Beach (NatMIP-RFCo-0004).

Diagnosis [128,132]: Fruticose or spherical rhodoliths with up to $5 \mathrm{~cm}$ of diameter densely branched with cup-shaped tips up to $6 \mathrm{~mm}$ in diameter, or forming smooth crusts $1-5 \mathrm{~mm}$ thick, becoming irregular at the junction of the edges with contiguous thalli (Figure 5A,B); thallus monomerous with plumose pluristratified hypothallus; in transverse view, synapses observed between cells of the same filament and between cells of neighbouring filaments; epithallus formed by 2 to 3 cell layers with $3-4 \mu \mathrm{m}$ in diameter (Figure 7A), each cell with thick upper calcified walls, sometimes triangular; lumen 3-4 $\mu \mathrm{m}$ length and 3-4 $\mu \mathrm{m}$ width; rectangular or oblong meristematic cells between epithalus and perithalus $12-25 \mu \mathrm{m}$ length and $6-8 \mu \mathrm{m}$ width; perithallus formed by ovoid cells 7-20 $\mu \mathrm{m}$ length and 4-7 $\mu \mathrm{m}$ width; pore canal (Figure 7B) cylindrical with a diameter of 55-70 $\mu \mathrm{m}$ and with an extension of 8-23 cells long (Figure 7C,D); bisporangia 70-87 $\mu \mathrm{m}$ length and 30-40 $\mu \mathrm{m}$ width; tetrasporangia 90-150 $\mu \mathrm{m}$ length and 40-65 $\mu \mathrm{m}$ width; colour pale to dark pink or purple (Figure $5 \mathrm{~A}, \mathrm{~B})$.

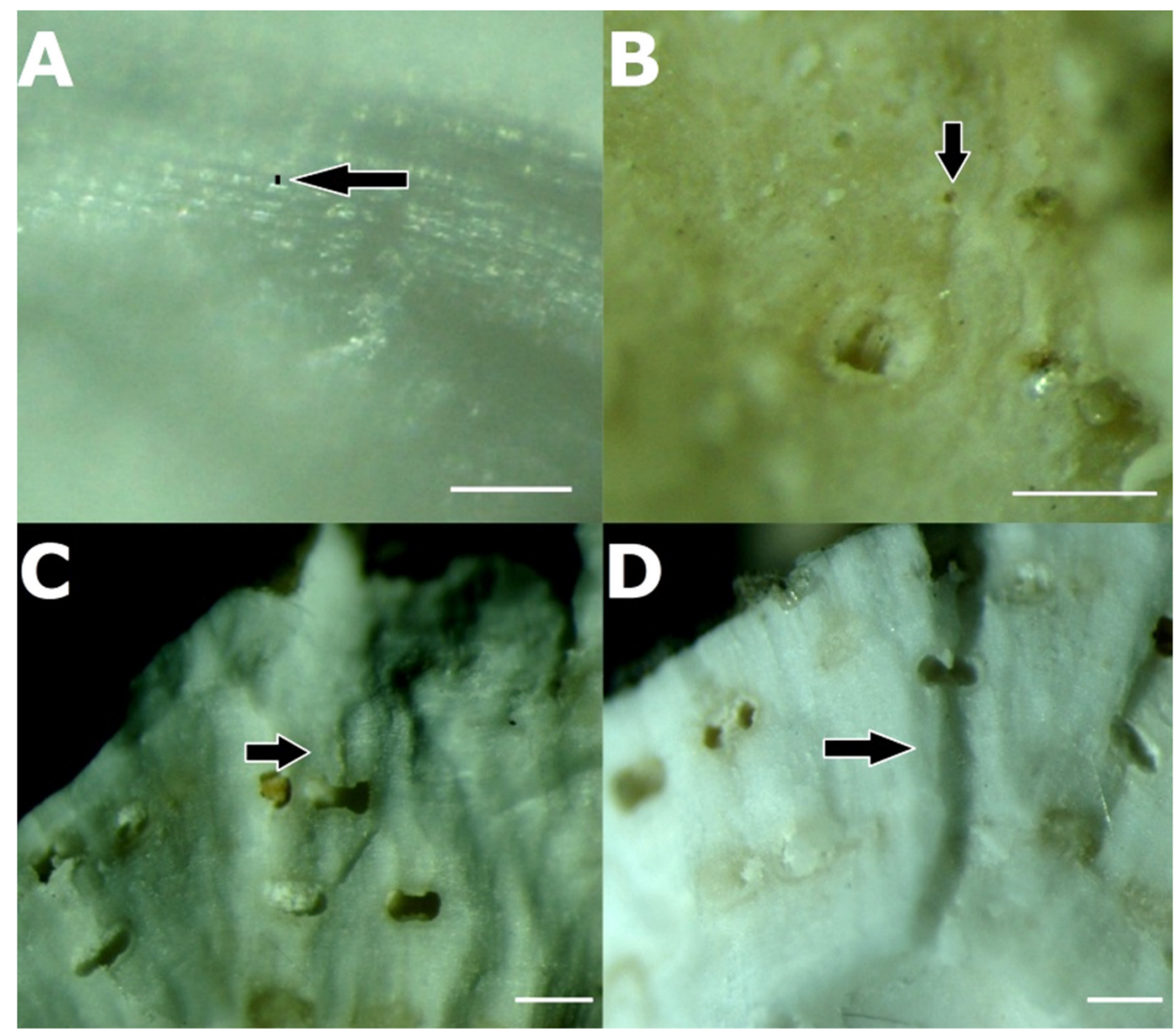

Figure 7. Lithophyllum hibernicum (NatMIP-RFCo-0001) structure details. Cell layers (A); Opening pore (B); Internal morphology of pore canal (C,D). Scales: (A): $50 \mu \mathrm{m}$; B-D: $250 \mu \mathrm{m}$. 
Geographical distribution. Northeast Atlantic: England, Ireland, France and Iberian Peninsula; Mediterranean: Spain and France [128].

Ecological notes. Found in epilithic crust on the mid to low intertidal zone in rock pools, bedrock and on tidal canals, epizoic on mussels and other bivalves, such as Mytilus sp., and as rhodolith on intertidal or subtidal zones up to $15 \mathrm{~m}$ on the Atlantic Ocean. On the Mediterranean Sea, was only found subtidally as rhodolith and as epiphytic crust on other rhodoliths like Lithophyllum incrustans [128].

\subsection{Association between P. ulyssiponensis and L. hibernicum}

The association was verified by the presence of rhodolith L. hibernicum on shell surface of limpet P. ulyssiponensis populations (Figure 6). The presence of this red calcareous alga was verified on all adult limpets, and one juvenile with $11.0 \mathrm{~mm}$ length from Belinho Beach (Esposende). It is also noted that juvenile limpets settle on the rhodolith surface [16], in a relationship similar to inquilinism or commensalism, and as the gastropods grow they feed on these calcareous algae, acquiring a more orange colouration. At the same time, rhodoliths begin to grow over the limpets, and may cover them completely behaving as epizoic. In speculative way, when limpets move to other environments, it is possible that transporting rhodoliths on your shell surface, may promote their dispersion.

\section{Discussion}

\subsection{Genetic Relationships of Two Patella ulyssiponensis Lineages}

Analyses of sequence data from the P. ulyssiponensis-aspera complex revealed strong genetic differentiation between Atlantic continental and insular populations, however insular populations are remarkably similar to some Italian populations (Figure 8). AMOVA analyses showing a $60 \%$ molecular variance between populations indicates somewhat structured populations. With 15 unique haplotypes for the Macaronesian regions, nine of them being exclusive to the Azores archipelagos, three exclusives to Madeira, three exclusives to Tenerife and one haplotype shared between Madeira, Tenerife and Fuerteventura and Bonifacio, France (Figures 10 and 11, Table S2).

Insular haplotypes are divided in two groups, one formed between Azores archipelago and Tenerife, and the other formed between Tenerife, Fuerteventura and Madeira islands. The large number of exclusive haplotypes with high diversity present in Azores might indicate this archipelago as occurring during a possible first colonization, via Tenerife for continental P. ulyssiponensis. Madeira and Canary have smaller haplotype diversity and share a haplotype with the continent, indicating recent gene flow (or intermittent gene flow) or low times of genetic drift. Azores and the Canary/Madeira group present a starlike haplotype network with a high ratio of singletons, indicating population expansion from a small number of founders following a bottleneck [139]. Insular haplotypes are more related to Italian haplotypes from Lo Strangolato with one minimum nucleotide mutation (Figure 10) between populations, although unsampled haplotypes may change the genealogy topology and solve the specific route of migration from continental to insular habitats. Sá-Pinto et al. suggested a differentiation between continental and insular lineages between 8.3 and 3.9 million years, with a basal haplotype for the Macaronesian Islands in Azores [140]. Nevertheless, our analysis with a larger dataset puts Tenerife as the basal haplotype, maintaining Azores the most differentiated group (Figure 10).

Although Mediterranean and Atlantic populations presented low differentiation indicating an ongoing genetic flow between these geographic areas, Mediterranean populations present a higher number of exclusive haplotypes, which might indicate the presence of barriers limiting gene flow, also suggested in [141], who pinpointed these barriers at the Almeria-Oran front and at South Italy, with the barrier at Almeria-Oran being supported by our own $\mathrm{F}_{\mathrm{ST}}$ calculations.

In the region of Agadir, Morocco (Atlantic) there are two exclusive haplotypes and one other haplotype shared between Portuguese, French Atlantic, Spanish populations, indicating a possible colonization from Iberian Peninsula (Figure 10). With the richest hap- 
lotype diversity on South Europe compared to northern Atlantic populations, the Western Mediterranean presents itself as strong candidate to this species ancestry. Although the differentiation between Atlantic continental and insular populations was found corroborating the analyses from Weber and Hawkins, and Sá-Pinto et al. [4,142], interspecific distances between Patella species range from 7 to $16 \%$ (with the exception of P. lugubris with P. candei) (Figure 9), and compared to the 3.5\% between the continental and insular lineages of the P. ulyssiponensis-aspera complex, and the fact that Mediterranean populations are genetically very close to insular populations, even sharing a haplotype indicates a case of ongoing speciation process, rather than being two different species. This speciation process is also corroborated by a large negative value of Tajima's D and Fu's FS for the Macaronesian regions, indicating a recent expansion due to an excess of singletons or recent mutations. Although Tajima's D for Madeira and Canary is non-significative Fu's FS is, being this contradiction probably resolved with a higher sequence sampling for this region. Similarly, Tajima's D and Fu's FS show non-significative contradictory results for Morocco, which might indicate a recent bottleneck or may have resulted from small sample size and small collection range, being restrained to only the Agadir region.

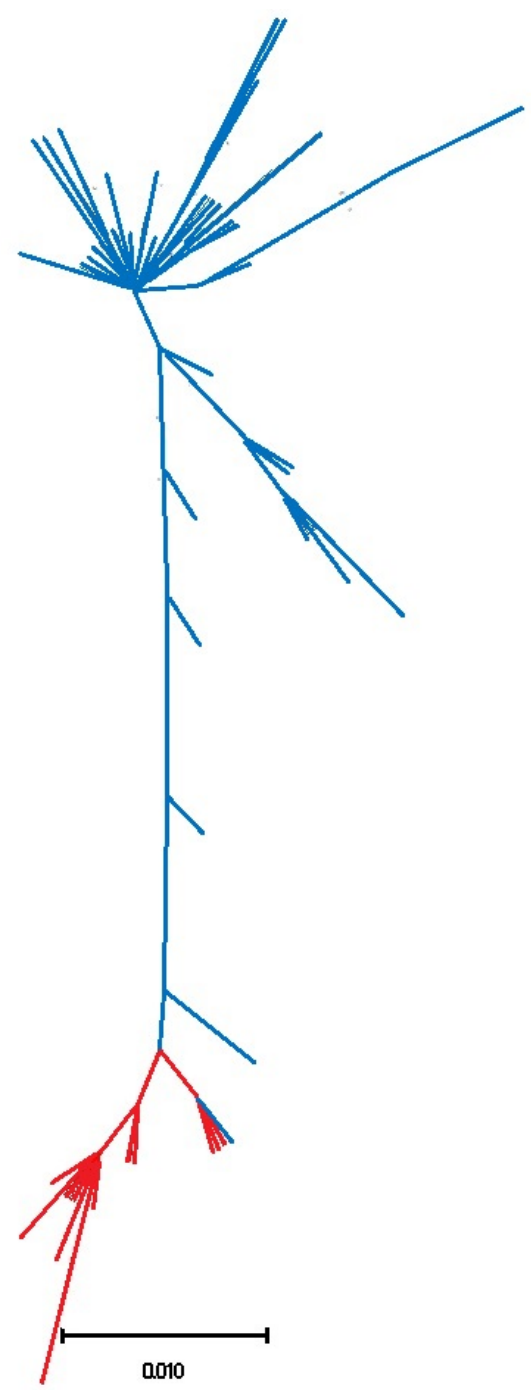

Figure 8. Maximum Likelihood radiated tree obtained for COI-5P sequences of Patella ulyssiponensis. Continental sequences represented in blue; Insular sequences represented in red. 


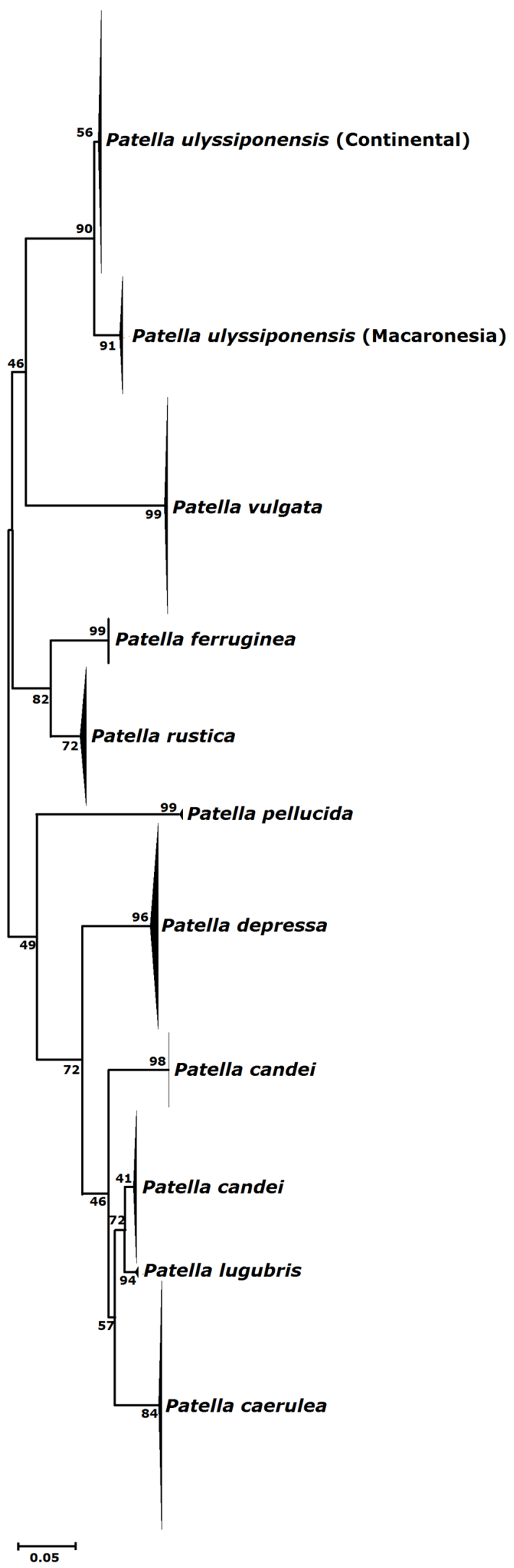

Figure 9. Maximum Likelihood tree obtained for COI-5P sequences of P. ulyssiponensis, P. vulgata, P. candei, P. caerulea, P. ferruginea, P. rustica, P. pelucida and P. depressa. Value of nodes corresponds to bootstrap support. 


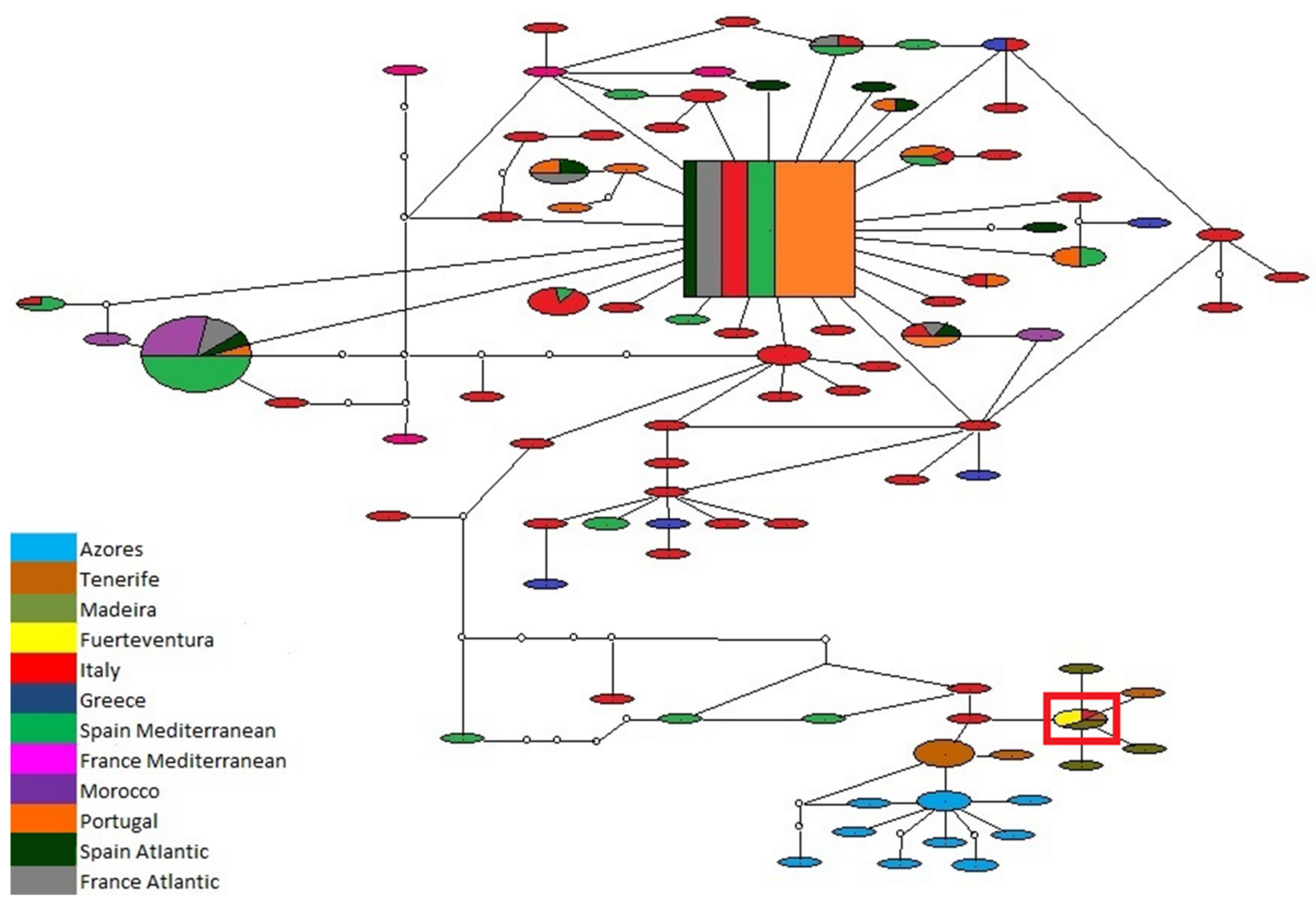

Figure 10. Haplotype networks (95\% parsimony connection limit) for sequences of Patella ulyssiponensis. Circle sizes are proportional to haplotype frequency coloured in accordance with the haplotype's presence in sampling locations. Non-observed haplotypes are represented by small white circles. Most probable ancestral haplotype represented by the largest square. Red square highlighting shared haplotype between insular and continental lineages.

\subsection{Biogeographic Patterns}

Nakano and Ozawa, based on the extant placement of Eoacmaea Nakano \& Ozawa, 2007 at the base of Patellogastropoda, inferred by molecular data and worldwide distribution of its recent species, suggested that this group was widespread in the Tethys Sea from the Lower Jurassic to Middle Cretaceous, with the diversification of Patellogastropoda occurring between the Jurassic and Cretaceous periods [88]. The oldest known fossil of Patellidae is Patella costulata Münster, 1869, found in the St. Cassian Formation in northern Italy from the Triassic (210-230 Mya), however generic assignment was impossible due to poor preservation $[2,143]$.

Due to the lack of fossil registers, the origin of the genus Patella was previously estimated, trough molecular divergence, to occur between the Upper Triassic and Upper Cretaceous, with a divergence from the rest of Patellidae estimated between 121-231 Mya [88] and between 69-169 Mya [144] with our estimations being similar to Koufopanou et al. results [144], ranging from 64.7-143 Mya (Figures 12 and 13A). Based on this time of origin and the distribution of its recent members, Patella spp. may have been the first Patellogastropoda to diversify in the Atlantic following its opening in the Jurassic, and may have been present in the northern Atlantic since the Mesozoic [88]. Following the closure of the Tethys Sea during the late Miocene, Patella may have been isolated from its sister group Scutellastra, suggesting a vicariant speciation [2] and explaining the mostly anti-tropical distribution of Patellidae (Figure 13B). 


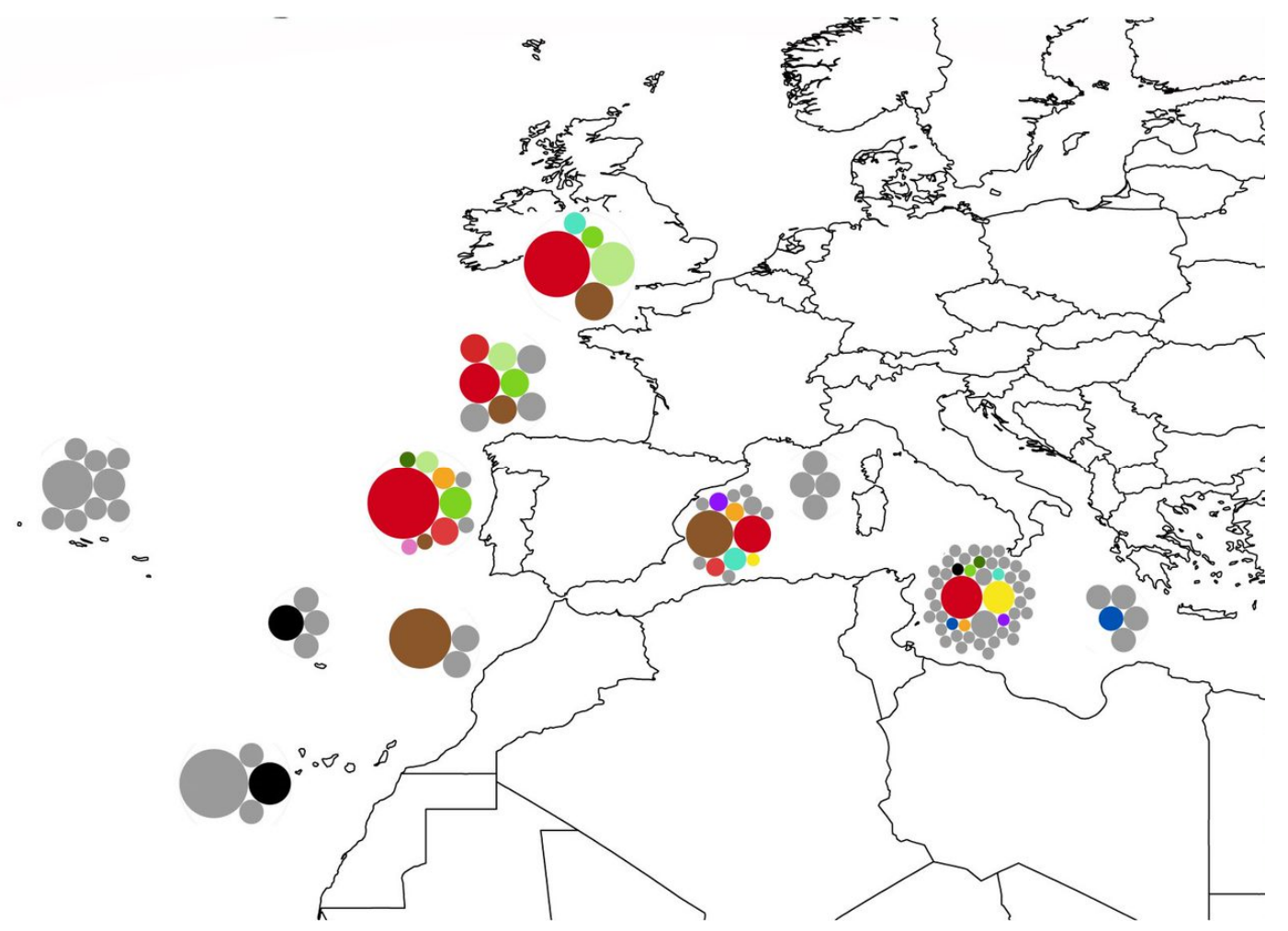

Figure 11. Haplotype distribution per sampling location (France Atlantic and Mediterranean; Spain Atlantic and Mediterranean; Portugal Continental; Azores; Madeira; Canary; Italy and Greece). Circle sizes are proportional to haplotype frequency for each locality. Grey circles represent haplotypes unique for that region, while coloured circles represent haplotypes shared between different sampling locations. Graphs constructed through rawgraphs.io.

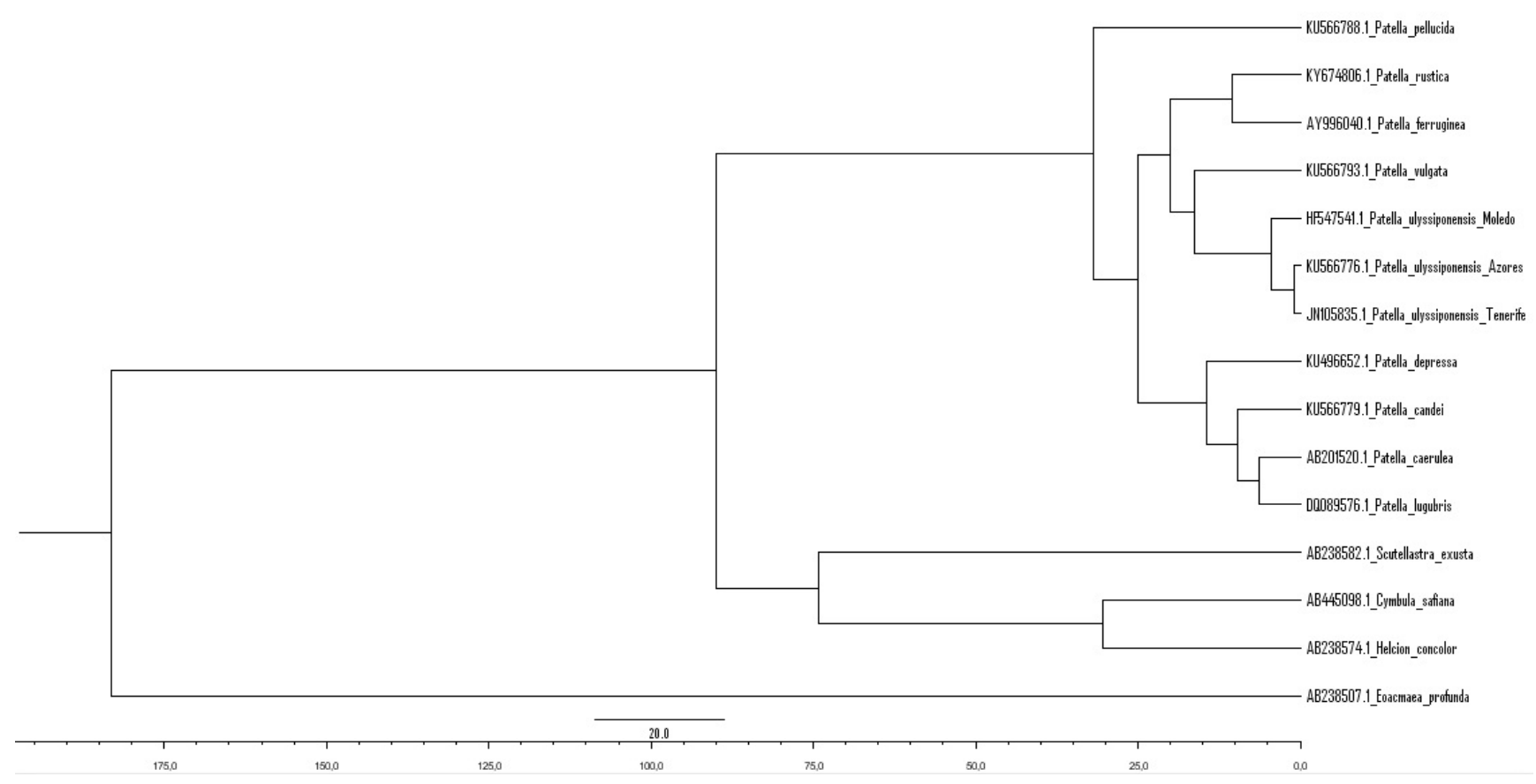

Figure 12. Estimation of The Most Recent Common Ancestor (TMRCA) tree for the family Patellidae. Scale in million years ago (Mya). 


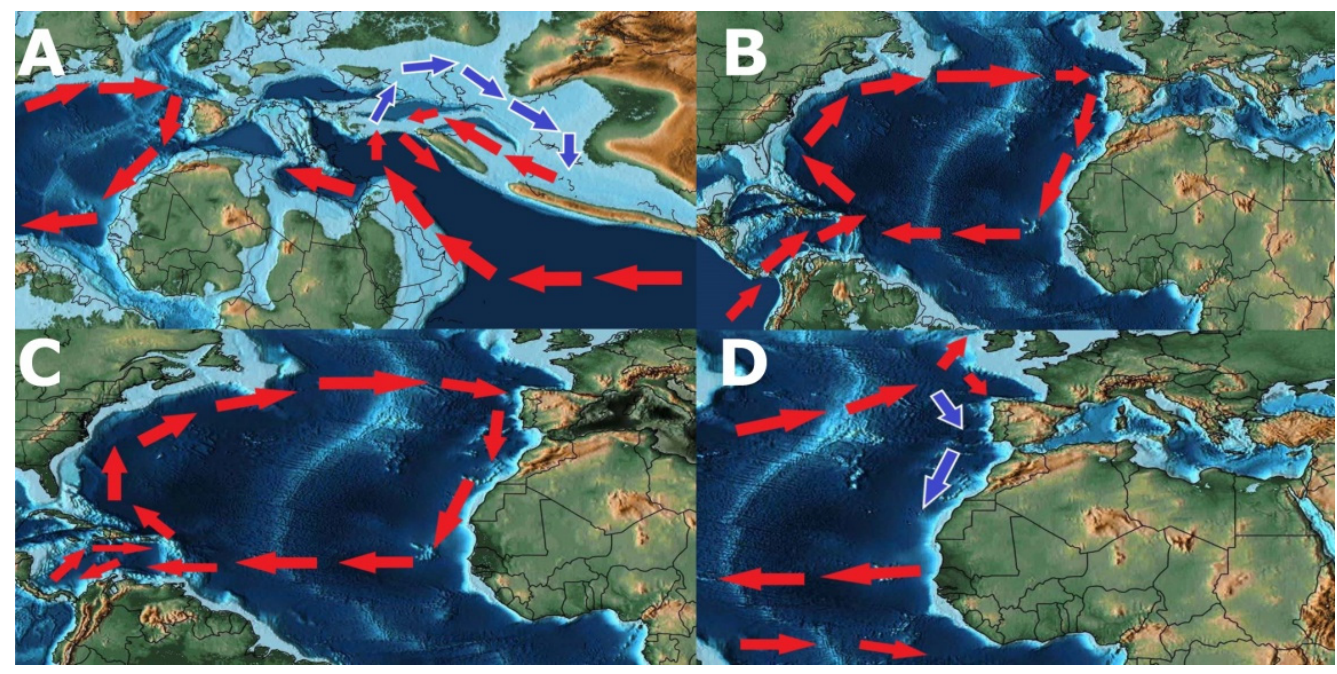

Figure 13. (A) Late Cretaceous (90 Mya): Post Pangea breakup; (B) Lower Miocene (20 Mya): Thetys Sea closure; (C) Upper Miocene (6 Mya): Messinian Salinity Crisis; (D) Lower Pliocene (4 Mya): Closure of the Isthmus of Panama. Red arrows: warm currents; Blue arrows: cold currents. Hypotheses for ocean currents (warm and cold) adapted from Britannica website [40]. Ancient satellite Earth images were obtained by the GPlates software, version 2.2.0.

Although Patella spp. may have its origin between the Upper Triassic to Upper Cretaceous, Koufopanou et al. suggested the radiation of the genus from 5-20 Mya [144], with our estimations putting that radiation ranging between 13.6-67.6 Mya, possibly being influenced by the emergence of the Macaronesian archipelagos, the closure and reopening of the Mediterranean (Figure 13C) and the Plio-Pleistocene glaciations. Crame noted a bipolar pattern among marine molluscs, suggesting three major phases of diversification: Jurassic-Cretaceous, Upper Palaeogene-Lower Neogene and Plio-Pleistocene-Recent [145].

The fossil record of the genus Patella is sparse, with only nine valid species according to WoRMS [1] (Table 6), although the full list of extinct species under Patella needs a revision due to the habit of assigning Patellidae taxa under Patella until the middle of the 19th century. From those nine extinct species, eight are from the Atlantic region, with three restricted to the Canary archipelagos and one from the Mediterranean, with extant dates ranging from the Oligocene to the Pleistocene. The disappearance of most of those species during the Miocene-Pliocene boundary might shed some light on the radiation of the extant species of Patella and its connection with the climactic change occurring within the Mediterranean and Macaronesian regions during this period.

Table 6. Known Patella fossil records according to MolluscaBase [146]. †, Extant/extinct species.

\begin{tabular}{|c|c|c|c|}
\hline Species & Period & Locality & Reference \\
\hline Patella alternicostata Sandberger, $1859+$ & Oligocene & Paris Basin, France & [147] \\
\hline Patella estotiensis Lozouet, $1999+$ & Upper Oligocene & Saint-Paul-lès-Dax, France & [148] \\
\hline Patella protea Doderlein, $1862+$ & Upper Miocene (Tortonian) & St-Clément-de-la-Place, France & [149] \\
\hline $\begin{array}{c}\text { Patella mahamensis Martín-González \& } \\
\text { Vera-Peláez, } 2018+\end{array}$ & Upper Miocene (Tortonian) & Fuerteventura, Spain & [150] \\
\hline $\begin{array}{c}\text { Patella maxoratensis Martín-González \& } \\
\text { Vera-Peláez, } 2018+\end{array}$ & Upper Miocene (Tortonian) & $\begin{array}{l}\text { Fuerteventura; Lanzarote; } \\
\text { Gran Canaria, Spain }\end{array}$ & [150] \\
\hline $\begin{array}{c}\text { Patella tintina Martín-González \& } \\
\text { Vera-Peláez, } 2018+\end{array}$ & Upper Miocene (Tortonian) & $\begin{array}{l}\text { Fuerteventura; Lanzarote; } \\
\text { Gran Canaria, Spain }\end{array}$ & [150] \\
\hline Patella ambroggii Lecointre, $1952+$ & Pliocene & Mogador, Atlantic Morocco & [151] \\
\hline $\begin{array}{c}\text { Patella alessiae Forli, Dell'Angelo, } \\
\text { Montagna \& Taviani, } 2004+\end{array}$ & Pliocene & Tuscany, Italy & [151] \\
\hline Patella hebertiana (d'Orbigny, 1850) † & - & Vigny, France & [152] \\
\hline
\end{tabular}


Regarding the known fossils of P. ulyssiponensis, the oldest one was found in the Contrada Case Alte region in Italy, dating from the Lower Pleistocene (2.6-0.8 Mya) [86], with two more from the Upper Pleistocene from Santa Maria, Azores $[48,50]$ and from the Canary islands Gran Canaria and Lanzarote [105].

Assuming the Jurassic-Cretaceous vicariance scenario as the origin of Patella, with the separation from its sister taxa (Scutellastra) through the breakup of Pangea and the Atlantic Ocean formation, followed by the closure of the Tethys seaway and successive closure of the connection between Indian and Atlantic Oceans during the Lower Miocene, the emergence of the Proto-Macaronesia archipelagos, the closure (before) and reopening (after this period) of the Mediterranean Sea during the Messinian Salinity Crisis and the closure of the passage on Isthmus of Panama (Table 7) as the radiation events for the genus Patella we propose the following scenarios for the origin and biogeography of Patella ulyssiponensis:

1. Possible origin of Patellogastropoda in Tethys Ocean (Figure 13A).

2. Vicariant speciation event during the breakup of the supercontinent of Pangea, originating two lineages that eventually led to the radiation of the genus Patella on the Northeast Atlantic Ocean and Scutellastra, Helcion and Cymbula on Southwest Africa (Figure 13B).

3. Radiation of the recent species of the genus Patella followed by the closure of the Tethys Sea with Patella ulyssiponensis appearing somewhere between the Upper Oligocene and the Lower Miocene (6.3-33.2 Mya) (Figure 13B).

4. Since from this event period, three hypotheses are proposed:

Hypothesis A-Separation of the Atlantic Iberian and Mediterranean populations during the Messinian Salinity Crisis, with isolation in refuges during the desiccation of the Mediterranean Sea, followed by a colonization of the Macaronesian archipelagos after the Zanclean Flood (Figure 13C). Supported by the higher number of exclusive haplotypes for the Mediterranean, including the basal one, by the proximity of insular and Mediterranean lineages and the divergence date between continental and insular lineages occurring after the Zanclean Flood ( 5.35 Mya). Followed by a colonization of the Northern Atlantic promoted by the deglaciations after the Last Glacial Maximum. Hypothesis B-Entrapment of Patella ulyssiponensis in the Mediterranean during the Messinian Salinity Crisis (Figure 13C), with the survival of some populations in refuges during the desiccation of the Sea and a posterior expansion in the Northeast Atlantic Ocean. Followed by a colonization of the Iberian and Northern Atlantic promoted by the deglaciations after the Last Glacial Maximum.

Hypothesis C-Entrapment in the Iberian Atlantic with the almost extinction in the Mediterranean during the Messinian Salinity Crisis (Figure 13C) followed by a rapid population and genetic expansion in the Mediterranean after the Zanclean Flood. This hypothesis is mainly proposed due to the lack of fossil evidence and lack of haplotype sampling for some locations which could resolve the non-observed haplotypes in the haplotype network tree.

Among the presented hypothesis we agree with hypothesis A, due to the presence of many exclusive haplotypes (including the most frequent one) in the Mediterranean, contrasting with the low haplotype diversity for the Northeast Atlantic, and the divergence date between continental and archipelago lineages occurring after the Zanclean Flood, according to TMRCA calculations

5. Interruption of the gene flow between the populations from Azores and the populations from Madeira/Canary, possibly due to the global rise of sea level, consequence of the interglacial events during the Plio-Pleistocene (3.15-0.1 Mya), submerging the Proto-Madeira and Proto-Canary archipelagos. The disappearance of these islands may have cut the pathways of dispersal trough the entirety of the Macaronesian archipelagos (Figure 13D).

As for the colonization of the Macaronesian archipelagos by P. ulyssiponensis, two possible pathways of dispersion are proposed: 
1. Transport by association with rhodoliths-The southeastern coasts of the Macaronesian archipelagos show abundant tempestite deposits that incorporate fossil rhodoliths, belonging to the Mid Miocene to Lower Pliocene [153], transported from eastern locations by storms [154]. Contrasting with the relative scarcity of rhodoliths in Madeira and Azores in present day [153], the Plio-Pleistocene might have rebalanced the circulation patterns, interrupting the gene flow between islands. In the present day, rhodolith debris is still found abundantly in Fuerteventura and seldomly found in Selvagens [153], which may explain the haplotypes shared between Madeira, Fuerteventura, Tenerife and Bonifacio (France).

2. Larval dispersal-Although no proof of long-range larval dispersal for Patella ulyssiponensis has been demonstrated, this pathway of colonization cannot be discarded. Contrary to other species of Patella, larvae of Patella ulyssiponensis show an optimal development at higher temperatures $\left(8-24{ }^{\circ} \mathrm{C}\right)$ and a higher larval longevity combined with a higher longevity in substratum absence [155]. All these aspects, associated with the presence of pathways via the Proto-Macaronesian archipelagos, may have an impact on long range larval dispersal during the warmer Upper Miocene (Figure 13C).

4.3. Historical Context and Morphology: Relationships between Patella ulyssiponensis Gmelin, 1791 and Patella aspera Röding, 1798

Limpet gastropods of genus Patella were first erected by Johann Friedrich Gmelin in "Systema Naturae" [41], designating 237 species, including P. ulyssiponensis, that was probably named for its sampling site, "Ulyssiponem", actual Lisbon, Portugal. This species was erected based on drawing in "La conchyliologie" (pl. 2, Figure G2, [162]). After this, Peter Friedrich Röding established the species P. aspera likewise according to the same image of the "La conchyliologie" book [60], as well as using this same illustration and specific designation methodology, Jean-Baptiste de Lamarck named P. aspera [61], which nowadays is considered as a junior homonym of P. aspera Röding, 1798 [163]. Observing only this historical contextualization, it may be considered that both taxa belong to the same species, with the older authority that should be the one used for the specific designation, namely P. ulyssiponensis [45], which is in line with the "Principle of Priority"-Article 23 of International Code of Zoological Nomenclature [164,165].

Synonymy of $P$. ulyssiponensis and $P$. aspera was primarily suggested by Joseph Christiaens [3]. This author indicated that the 1780 's work referred inaccurately to Patagonia (South America) for limpet sampling (pl. 2, Fig. G2 [162]), which may have instead been collected in the Azores, Portugal [3]. Christiaens suggested the use of P. ulyssiponensis aspera for the subspecies of P. ulyssiponensis present on the Atlantic islands [3]. In the Checklist of British Marine Mollusca, the authors also considered P. aspera as a synonym of P. ulyssiponensis [166]. Sella, Robotti and Biglione also assumed that both species are the same in a study about genetic divergence among Mediterranean Patella spp. [167]. Posteriorly, Titselaar also considered P. aspera as a synonym of P. ulyssiponensis, and designated a neotype for a specimen of P. ulyssiponensis collected in Estoril, Portugal [46], which is $24 \mathrm{~km}$ away from the type locality (Lisbon). In a morphometric analysis of northwest Portuguese limpets, Cabral and Silva mentioned Röding and Lamarck's P. aspera as a synonym of P. ulyssiponensis [52]; Mauro et al. also considered both species as the same [168]. 
Table 7. Summary of most significant geological events and possible geological and climatic outcomes.

\begin{tabular}{|c|c|c|c|c|}
\hline Event & Date & Geographical Outcome & Ocean Current Pattern & References \\
\hline Pangea breakup & $\begin{array}{l}\text { Lower Jurassic (145 Mya) to } \\
\text { Lower Cretaceous (110 Mya) }\end{array}$ & $\begin{array}{l}\text { PaleoAfrica separation; } \\
\text { Atlantic Ocean formation }\end{array}$ & $\begin{array}{c}\text { Influx of the warm current from the } \\
\text { Tethys Sea to the newly formed } \\
\text { Atlantic Ocean }\end{array}$ & [156-158] \\
\hline Tethys closure & $\begin{array}{l}\text { Oligocene-Miocene } \\
35 \text { to } 20 \text { Mya }\end{array}$ & $\begin{array}{c}\text { Collision of Arabian and Eurasia plates; } \\
\text { Atlantic and Indian Oceans } \\
\text { definitive separation }\end{array}$ & $\begin{array}{l}\text { Influx of the warm current from the Pacific to } \\
\text { all the Atlantic up to the United Kingdom; } \\
\text { Total interruption of the current exchange } \\
\text { between the Indic and Atlantic Oceans }\end{array}$ & [159] \\
\hline $\begin{array}{l}\text { Emergence and submersal of } \\
\text { Proto-Madeira, Proto-Canary and } \\
\text { Proto-Azores archipelagos }\end{array}$ & 60 to 8 Mya & $\begin{array}{l}\text { Emergence of Gettysburg/Ormonde and Lars } \\
\text { (60 Mya); Emergence of Great Meteor (16 Mya); } \\
\text { Emergence of Porto Santo and Gran Canaria } \\
\text { (10 Mya); Emergence of Santa Maria (8 Mya) }\end{array}$ & $\begin{array}{c}\text { Great influx of the warm current from the } \\
\text { Pacific to all the Proto-Macaronesian } \\
\text { archipelagos }\end{array}$ & {$[160,161]$} \\
\hline Messinian Salinity Crisis & 5.9 to $5.3 \mathrm{Mya}$ & $\begin{array}{l}\text { Closure of the Gibraltar Strait and subsequent } \\
\text { desiccation of the Mediterranean Sea; } \\
\text { Reopening of the Atlantic connection } \\
\text { (Zanclean Flood) }\end{array}$ & $\begin{array}{l}\text { Warm tides cycling on the } \\
\text { North Atlantic Sea flows }\end{array}$ & [159] \\
\hline $\begin{array}{l}\text { Isthmus of Panama } \\
\text { passage closure }\end{array}$ & 3.2 to $2.6 \mathrm{Mya}$ & $\begin{array}{l}\text { Formation of the land connection between } \\
\text { North and South America }\end{array}$ & $\begin{array}{l}\text { Apearence of the cold Canarian current } \\
\text { (Canarian climate change from } \\
\text { Tropical to Mediterranean) }\end{array}$ & {$[159,160]$} \\
\hline Plio-Pleistocene glaciations & 2.7 Mya to $18 \mathrm{kyr}$ & Multiple interglacial periods & $\begin{array}{l}\text { Loss of land mass on Macaronesian } \\
\text { archipelagos, } \\
\text { with each island becoming more isolated }\end{array}$ & {$[159,160]$} \\
\hline
\end{tabular}


In relation to rhodolith-forming algae species, in 1897, Mikael Heggelund Foslie erected a variety for species Lithothamnion fasciculatum (Lamarck) Areschoug, 1852, identified as $L$. fasciculatum $\mathrm{f}$. subtilis, with the remarkable characteristic of ramifications shorter than other varieties established in the same work (i.e., L. fasciculatum f. incrassata, f. gyrosa, and f. dilatata), and narrowed (1 to $1.5 \mathrm{~mm}$ width) compared to L. fasciculatum f. incrassata [137]. In 1906, the same author revised this identification and replaced the genus with Lithophyllum, re-naming for Lithophyllum hibernicum [120]. This last designation was, therefore, established and used in other subsequent studies (see Section 3.2 Taxonomic Account-Lithophyllum hibernicum).

\subsection{Limpets and Rhodoliths}

The existence of epizoic algae on the hard shell of molluscs is a small, sparse and poorly understood research topic; thus, the ecological importance of this relationship is sometimes overlooked [169]. Calcareous red algae are able to grow on stone shores (epilithic forms), as well as on biological structures, i.e., epiphytic types growing on other algae, and epizoic carbonate algae on alive and dead animals: on shell fragments, gastropods, bivalves, barnacles [170], sponges, corals, or sea urchins [171,172]. In relation to genus Lithophyllum, associations between Lithophyllum incrustans Philippi, 1837 and a snail shell [173], or between Lithophyllum hibernicum Foslie, 1906 and the bivalve Mytilus galloprovincialis Lamarck, 1819 [174] have already been observed (Figure 2B,C). The association between P. ulyssiponensis and L. hibernicum is described for the first time. An ecological relationship between the two species, benefiting the limpet at a certain stage of its life cycle (settlement) and even as camouflage to protect it from predation should be further investigated.

Haplotype's network of this limpet indicates that the distribution and historical dispersion originated from Mediterranean Sea, until arrival to European Atlantic and Macaronesian islands (Figures 10 and 11). For L. hibernicum, the actual distribution ranges from the Mediterranean Sea to European Atlantic, but there are no records for the Atlantic islands. Nonetheless, fossil registers may help to understand the rhodolith-limpet relationship. For example, Johnson et al. identified many Pleistocene stratigraphic profiles containing rhodoliths (including Lithophyllum sp.) at the Cape Verde Islands [175]. They also verified the presence of Patella sp. (and other molluscs) in same strata of rhodoliths [175], similarly to the first work performed in the same study area by Charles Darwin, that found many shells fossils, including limpet specimens, with rhodoliths formation [176].

\section{Conclusions}

According to morphological and genetic analyses, both P. ulyssiponensis and P. aspera are the same species, existing in continental and insular shore environments, influenced by the Northeast Atlantic Ocean and Mediterranean Sea, and probably surviving the Messinian Salinity Crisis event. The current distribution and ecological release may be associated with the Atlantic Ocean tides after the opening of the Strait of Gibraltar (end of Messinian Crisis). In this context, among the presented hypothesis, we agree with the first hypothesis, due to the many exclusive haplotypes (including the most frequent one) for the Mediterranean, contrasting with the low haplotype diversity for the Northeast Atlantic, and their divergence date between continental and archipelago lineages occurring after the Zanclean Flood, according to TMRCA calculations. Therefore, it is very possible that limpets survived the Messinian event, following susceptible dispersions on Atlantic islands.

Rhodolith-forming algae L. hibernicum may influence the settlement and dispersal of limpet larvae, but on the other hand possesses an epizoic relationship on the adult shell surface of $P$. ulyssiponensis. This probable association can currently be considered as a profitable case of co-evolution of both species.

The fossil record of Patellogastropoda is poorly known, due to the rarity of their fossils, mostly because of their occurrence on wave exposed rocky shores in which conditions for preservation are limited. This scarce knowledge is also compounded by a lack of shell microstructure examination, causing genera and family misplacements. Consequently, the 
divergence time estimated from genetic distances and calibrations based on a small number of fossil records can result in its underestimation or overestimation. Concerning the origin and lineages divergence times of P. ulyssiponensis, an expansion of sampling locations might provide some insights and solve some patterns, especially by having a higher sampling effort in the Iberian Atlantic, Macaronesia archipelagos and Moroccan coast, and by the inclusion of sequences from the African Mediterranean, Black Sea and Northern Atlantic Regions, combined with a compilation of datasets based on multiple genes.

Supplementary Materials: The following are available online at https:/ / www.mdpi.com/article/ 10.3390/hydrobiology1010003/s1, Figure S1: Maximum Likelihood tree obtained for COI-5P sequences of Patella ulyssiponensis, using HKY + G substitution model. Value of nodes corresponds to bootstrap support. Figure S2: Bayesian consensus tree of COI-5P for Patella ulyssiponensis. Node values correspond to Bayesian posterior probabilities. Table S1: List of COI-5P sequences for Patellogastropoda with GenBank accession numbers. Table S2: Haplotype frequencies for COI-5P Patella ulyssiponensis sequences.

Author Contributions: D.d.A.C. designed the study and performed taxonomic, and nomenclatural revision. D.d.A.C. and N.G. interpreted and analysed the data, including biogeographic approach. N.G. performed genetic analyses. D.d.A.C. and N.G. prepared the figures. D.d.A.C. and N.G. wrote the first draft of the manuscript with significant contributions from C.A. C.A. realized English review of whole manuscript. All authors have read and agreed to the published version of the manuscript.

Funding: This research received no external funding.

Institutional Review Board Statement: Not applicable.

Informed Consent Statement: Not applicable.

Data Availability Statement: Obtained DNA sequence available at: https:/ / www.ncbi.nlm.nih.gov / nuccore/ ok465193 (accessed on 16 November 2021).

Acknowledgments: Authors acknowledge the Interdisciplinary Centre of Marine and Environmental Research (CIIMAR) and Aquamuseu do Rio Minho institutes for providing laboratories and facilities that allow the development of whole research procedures. Special thanks to Vanessa Modesto (Italian National Research Council, Institute of Water Research IRSA) and Duarte Gonçalves (CIIMAR) for the brief review in the manuscript.

Conflicts of Interest: The authors declare no conflict of interest.

\section{References}

1. WoRMS Patella Linnaeus. 1758. Available online: http://www.marinespecies.org/aphia.php? $\mathrm{p}=$ taxdetails\&id=138312 (accessed on 5 May 2021).

2. Ridgway, S.A.; Reid, D.G.; Taylor, J.D.; Branch, G.M.; Hodgson, A.N. A cladistic phylogeny of the family Patellidae (Mollusca: Gastropoda). Philos. Trans. R. Soc. Lond. Ser. B: Biol. Sci. 1998, 353, 1645-1671. [CrossRef]

3. Christiaens, J. Révision du genre Patella (Mollusca, Gastropoda); Muséum National D’histoire Naturelle: Paris, France, 1973; Volume 121, pp. 1305-1392.

4. Weber, L.I.; Hawkins, S.J. Patella aspera and P. ulyssiponensis: Genetic evidence of speciation in the North-east Atlantic. Mar. Biol. 2005, 147, 153-162. [CrossRef]

5. Hayward, P.J.; Ryland, J.S. Handbook of the Marine Fauna of North-West Europe, 2nd ed.; Hayward, P.J., Ryland, J.S., Eds.; Oxford University Press: New York, NY, USA, 2017; ISBN 9780199549443.

6. CICON Морское блюдечко-Patella ulyssiponensis Gmelin. 1791. Available online: https://cicon.ru/morskoe-blyudechko-krym. html (accessed on 8 April 2021).

7. Guerra, M.T.; Gaudencio, M.J. Aspects of the ecology of Patella spp. on the Portuguese coast. Hydrobiologia 1986, 142, 57-69. [CrossRef]

8. Kooistra, W.H.C.F.; Joosten, A.M.T.; van den Hoek, C. Zonation Patterns in Intertidal Pools and their Possible Causes: A Multivariate Approach. Bot. Mar. 1989, 32, 9-26. [CrossRef]

9. Firth, L.B.; Crowe, T.P. Large-scale coexistence and small-scale segregation of key species on rocky shores. Hydrobiologia 2008, 614, 233-241. [CrossRef]

10. Spencer Davies, P. Physiological ecology of Patella I. The effect of body size and temperature on metabolic rate. J. Mar. Biol. Assoc. UK 1966, 46, 647-658. [CrossRef] 
11. Martins, H.R.; Santos, R.S.; Hawkins, S.J. Exploitation of limpets (Patella spp.) in the Azores with a preliminary analysis of the stocks. ICES Rep. 1987, 53, 1-18.

12. Vasconcelos, P.; Umapathy, U.; Moura, P.; Pereira, F.; Carvalho, A.N.; Gaspar, M.B. Size at sex change and reproductive cycle of the limpets Patella vulgata and Patella ulyssiponensis (Mollusca: Patellogastropoda) from intertidal rocky shores of the Algarve coast (southern Portugal). Invertebr. Reprod. Dev. 2019, 63, 294-308. [CrossRef]

13. Faria, J.; Pita, A.; Martins, G.M.; Ribeiro, P.A.; Hawkins, S.J.; Presa, P.; Neto, A.I. Inbreeding in the exploited limpet Patella aspera across the Macaronesia archipelagos (NE Atlantic): Implications for conservation. Fish. Res. 2018, 198, 180-188. [CrossRef]

14. Hawkins, S.J.; Pannacciulli, F.G.; Weber, L.C.; Bishop, J.D.D. Thoughts on the ecology and evolution of the intertidal biota of the Azores and other Atlantic islands. Hydrobiologia 2000, 440, 3-17. [CrossRef]

15. Sanna, D.; Dedola, G.L.; Lai, T.; Curini-Galletti, M.; Casu, M. PCR-RFLP: A practical method for the identification of specimens of Patella ulyssiponensis s.l. (Gastropoda: Patellidae). Ital. J. Zool. 2012, 79, 50-59. [CrossRef]

16. Seabra, M.I.; Cruz, T.; Fernandes, J.N.; Silva, T.; Hawkins, S.J. Recruitment of the limpet Patella ulyssiponensis and its relationship with crustose coralline algae: Patterns of juvenile distribution and larval settlement. J. Mar. Biol. Assoc. UK 2019, 99, 1787-1796. [CrossRef]

17. Bowman, R.S. The morphology of Patella spp. juveniles in Britain, and some phylogenetic inferences. J. Mar. Biol. Assoc. UK 1981, 61, 647-666. [CrossRef]

18. Woelkerling, W.J.; Irvine, L.M.; Harvey, A.S. Growth-forms in non-geniculate coralline red algae (Corallinales, rhodophyta). Aust Syst. Bot. 1993, 6, 277-293. [CrossRef]

19. Sañé, E.; Chiocci, F.L.; Basso, D.; Martorelli, E. Environmental factors controlling the distribution of rhodoliths: An integrated study based on seafloor sampling, ROV and side scan sonar data, offshore the W-Pontine Archipelago. Cont. Shelf Res. 2016, 129, 10-22. [CrossRef]

20. Johansen, H.W. Coralline Algae, A First Synthesis; CRC Press: Boca Raton, FL, USA, 1981.

21. Riosmena-Rodríguez, R.; Nelson, W.; Aguirre, J. Rhodolith/Maërl Beds: A Global Perspective; Riosmena-Rodríguez, R., Nelson, W., Aguirre, J., Eds.; Coastal Research Library; Springer International Publishing: Cham, Switzerland, 2017; Volume 15, ISBN 978-3-319-29313-4.

22. Barbera, C.; Bordehore, C.; Borg, J.A.; Glémarec, M.; Grall, J.; Hall-Spencer, J.M.; de la Huz, C.; Lanfranco, E.; Lastra, M.; Moore, P.G.; et al. Conservation and management of northeast Atlantic and Mediterranean maerl beds. Aquat. Conserv. Mar. Freshw. Ecosyst. 2003, 13, S65-S76. [CrossRef]

23. Peña, V.; Bárbara, I. Non-coralline crustose algae associated with maerl beds in Portugal: A reappraisal of their diversity in the Atlantic Iberian beds. Bot. Mar. 2013, 56, 481-493. [CrossRef]

24. Baweja, P.; Kumar, S.; Sahoo, D.; Levine, I. Biology of Seaweeds. In Seaweed in Health and Disease Prevention; Elsevier: Amsterdam, The Netherlands, 2016; pp. 41-106. ISBN 9780128027936.

25. Adey, W.H. The effects of light and temperature on growth rates in boreal-subarctic crustose corallines. J. Phycol. 1970, 6, 269-276. [CrossRef]

26. Lobo, J.; Costa, P.M.; Teixeira, M.A.L.; Ferreira, M.S.G.; Costa, M.H.; Costa, F.O. Enhanced primers for amplification of DNA barcodes from a broad range of marine metazoans. BMC Ecol. 2013, 13, 34. [CrossRef]

27. Kumar, S.; Stecher, G.; Li, M.; Knyaz, C.; Tamura, K. MEGA X: Molecular Evolutionary Genetics Analysis across Computing Platforms. Mol. Biol. Evol. 2018, 35, 1547-1549. [CrossRef]

28. Hebert, P.D.N.; Ratnasingham, S. The Barcode of Life Data System BOLD. Mol. Ecol. Notes 2007, 7, 355-364. [CrossRef]

29. Altschul, S.F.; Gish, W.; Miller, W.; Myers, E.W.; Lipman, D.J. Basic local alignment search tool. J. Mol. Biol. 1990, 215, 403-410. [CrossRef]

30. Benson, D.A. GenBank. Nucleic Acids Res. 2004, 33, D34-D38. [CrossRef] [PubMed]

31. Posada, D. jModelTest: Phylogenetic model averaging. Mol. Biol. Evol. 2008, 25, 1253-1256. [CrossRef] [PubMed]

32. Huelsenbeck, J.P.; Ronquist, F. MRBAYES: Bayesian inference of phylogenetic trees. Bioinformatics 2001, 17, 754-755. [CrossRef]

33. Clement, M.; Posada, D.; Crandall, K.A. TCS: A computer program to estimate gene genealogies. Mol. Ecol. 2000, 9, 1657-1659. [CrossRef]

34. Peakall, R.; Smouse, P.E. GenALEx 6.5: Genetic analysis in Excel. Population genetic software for teaching and research-An update. Bioinformatics 2012, 28, 2537-2539. [CrossRef]

35. Excoffier, L.; Lischer, H.E.L. Arlequin suite ver 3.5: A new series of programs to perform population genetics analyses under Linux and Windows. Mol. Ecol. Resour. 2010, 10, 564-567. [CrossRef]

36. Suchard, M.A.; Lemey, P.; Baele, G.; Ayres, D.L.; Drummond, A.J.; Rambaut, A. Bayesian phylogenetic and phylodynamic data integration using BEAST 1.10. Virus Evol. 2018, 4, vey016. [CrossRef]

37. Marko, P.B. Fossil Calibration of Molecular Clocks and the Divergence Times of Geminate Species Pairs Separated by the Isthmus of Panama. Mol. Biol. Evol. 2002, 19, 2005-2021. [CrossRef]

38. Rambaut, A.; Drummond, A.J.; Xie, D.; Baele, G.; Suchard, M.A. Posterior Summarization in Bayesian Phylogenetics Using Tracer 1.7. Syst. Biol. 2018, 67, 901-904. [CrossRef]

39. Müller, R.D.; Cannon, J.; Qin, X.; Watson, R.J.; Gurnis, M.; Williams, S.; Pfaffelmoser, T.; Seton, M.; Russell, S.H.J.; Zahirovic, S. GPlates: Building a Virtual Earth Through Deep Time. Geochem. Geophys. Geosyst. 2018, 19, 2243-2261. [CrossRef]

40. Encyclopædia Britannica Britannica Website. Available online: https:/ / www.britannica.com/ (accessed on 6 October 2021). 
41. Gmelin, J.F. Vermes. In Caroli a Linné. Systema Naturae per Regna Tria Naturae; Gmelin, J.F., Ed.; G.E. Beer: Leipzig, Germany, 1791; pp. 3021-3910.

42. Dillwyn, L.W. A Descriptive Catalogue of Recent Shells: Arranged According to the Linnæan Method; with Particular Attention to the Synonymy; Printed for John and Arthur Arch: London, UK, 1817.

43. Blainville, H.M. Dictionnaire des Sciences Naturelles, Dans Lequel on Traite Méthodiquement des Différens Êtres de la Nature, Considérés Soit en Eux-Mêmes, D'après L'état Actuel de nos Connoissances, Soit Relativement à L'utilité Qu'en Peuvent Retirer la Médecine, L'agric; Levrault; Tome, 38; Le Normant: Paris, France, 1825.

44. Christiaens, J. Additifs à la "Révision du genre Patella". Inf. Soc. Belg. Malacol. 1974, 5, 63-68.

45. Ortea, J.A. El género Patella Linné 1758 en Asturias. Boletín Cienc. Nat. Inst. Estud. Astur. 1980, 26, 57-72.

46. Titselaar, F.F.L.M. A revision of the recent European Patellidae (Mollusca: Gastropoda). Vita Mar. 1998, 45, 21-62.

47. Öztürk, B.; Ergen, Z. Patella species (Archaeogastropoda) distributed in Saros Bay (Northest Aegean Sea) [Saros körfezi'nde (Kuzey Ege Denizi) dağilim gösteren Patella (Archaeogastropoda) türleri]. Turkish J. Zool. 1999, 23, 513-519.

48. Callapez, P.; Soares, A.F. Late Quaternary warm marine mollusks from Santa Maria (Azores); paleoecologic and paleobiogeographic considerations. Ciências Terra 2000, 14, 313-322.

49. Bouchet, P.; Le Renard, J.; Gofas, S. Mollusca. In European Register of Marine Species: A Check-List of the Marine Species in Europe and a Bibliography of Guides to their Identification; Costello, M.J., Emblow, C., White, R.J., Eds.; Muséum National d'Histoire Naturelle, Institute D'écologie et de Gestion de la Biodiversité Service du Patrimoine Naturel: Paris, France, 2001; pp. 180-213.

50. Ávila, S.P.; Amen, R.; Azevedo, J.M.N.; Cachão, M.; García-Talavera, F. Checklist of the Pleistocene Marine Molluscs of Praínha and Lagoínhas (Santa Maria Island, Azores). Açoreana. Rev. Estud. Açoreanos 2002, 9, 343-370.

51. Cabral, J.P. Characterization and multivariate analysis of Patella intermedia, Patella ulyssiponensis and Patella vulgata from Póvoa de Varzim (Northwest Portugal). Iberus Rev. la Soc. Española Malacol. 2003, 21, 1-17.

52. Cabral, J.P.; Silva, A.C.F. Morphometric analysis of limpets from an Iron-Age shell midden found in northwest Portugal. J. Archaeol. Sci. 2003, 30, 817-829. [CrossRef]

53. Cabral, J.P. Shape and growth in European Atlantic Patella limpets (Gastropoda, Mollusca). Ecological implications for survival. Web Ecol. 2007, 7, 11-21. [CrossRef]

54. Hodgson, A.N.; Le Quesne, W.J.F.; Hawkins, S.J.; Bishop, J.D.D. Factors affecting fertilization success in two species of patellid limpet (Mollusca: Gastropoda) and development of fertilization kinetics models. Mar. Biol. 2007, 150, 415-426. [CrossRef]

55. Dhora, D. Mollusks of Albania. Arch. Biol. Sci. 2009, 61, 537-553. [CrossRef]

56. Ivanov, S.P.; Fateryga, A.V. Красная Книга Республики Крым: Жиивотные[Red Book of the Republic of Crimea: Animals]; PP "ARIAL" LLC: Simferopol, Republic of Crimea, 2015; ISBN 9785906813886.

57. Borges, L.M.S.; Hollatz, C.; Lobo, J.; Cunha, A.M.; Vilela, A.P.; Calado, G.; Coelho, R.; Costa, A.C.; Ferreira, M.S.G.; Costa, M.H.; et al. With a little help from DNA barcoding: Investigating the diversity of Gastropoda from the Portuguese coast. Sci. Rep. 2016, 6, 20226. [CrossRef] [PubMed]

58. Titselaar, F.F.L.M. Notes on the nomenclature of the Macaronesian Patella candei d'Orbigny complex, with special reference to Patella ordinaria Mabile and Patella crenata Gmelin (Patellogastropoda, Patellida). Basteria 2019, 4-6, 158-165.

59. Crocetta, F.; Bitar, G.; Zibrowius, H.; Oliverio, M. Increase in knowledge of the marine gastropod fauna of Lebanon since the 19th century. Bull. Mar. Sci. 2020, 96, 5343. [CrossRef]

60. Röding, P.F. Museum Boltenianum, Sive, Catalogus Cimeliorum e Tribus Regnis Naturae Quae Olim Collegerat Joa. Fried. Bolten ... : Pars Secunda Continens Conchylia Sive Testacea Univalvia, Bivalvia \& Multivalvia; Typis Johan. Christi. Trappii: Hamburgi, Germany, 1798.

61. De Lamarck, J.-B. Histoire Naturelle des Animaux Sans Vertèbres; Verdiere, Libraire: Paris, France, 1819.

62. Reeve, L.A. Conchologia Iconica: Or, Illustrations of the Shells of Molluscous Animals; Lovell Reeve: London, UK, 1855; Volume VIII.

63. Servain, G. Étude sur les Patellidae des Mers d'Europe; Germain \& G. Grassin: Angers, France, 1886.

64. Simroth, H. Zur Kenntniss der Azorenfauna. Arch. für Nat. 1888, 54, 179-234.

65. Watson, R.B. On the Marine Mollusca of Madeira; with Descriptions of Thirty-five new Species, and an Index-List of all the known Sea-dwelling Species of that Island. J. Linn. Soc. Lond. Zool. 1897, 26, 233-329. [CrossRef]

66. Nobre, A. Materiais Para o Estudo da Fauna dos Açores; Instituto de Zoologia da Universidade do Porto: Porto, Portugal, 1930.

67. Mermod, G. Les Types de la Collection Lamarck au Muséum de Genève. Mollusques vivants, I. Rev. Suisse Zool. 1950, 57, 687-756. [CrossRef]

68. Evans, R.G. Studies on the biology of British limpets-the genus Patella on the south coast of England. Proc. Zool. Soc. Lond 1953, 123, 357-376. [CrossRef]

69. Evans, R.G. The genus Patella on the West coast of France. J. Conchyliol. 1958, 98, 126-151.

70. Fischer-Piette, E.; Gaillard, J.M. Les patelles, au long des cotes Atlantiques Ibériques et Nord-Marocaines. J. Conchyliol. 1959, 99, 135-200.

71. Kolstad, K. Patella aspera Lamarck, New to Norway. Nature 1959, 184, 1886-1887. [CrossRef]

72. Morton, B. Malacological Report. In Final Report Published by Chelsea College Azores Expedition (July-October 1965); Chelsea College of Science and Technology, University of London: London, UK, 1967; pp. 30-39.

73. McMillan, N.F. British Shells; F. Warne: London, UK, 1968; ISBN 0723209650.

74. Nordsieck, F. Die europäischen Meeres-Gehäuseschnecken (Prosobranchia). Vom Eismeer bis Kapverden und Mittelmeer; Gustav Fischer: Stuttgart, Germany, 1968. 
75. Powell, A.W.B. The patellid limpets of the world (Patellidae). Indo-Pac. Mollusca 1973, 3, 75-206.

76. Cuerda, J.; Galiana, R. Nuevo yacimiento del Pleistoceno superior marino en la costa norte de Mallorca. Bolletí Soc. d'Història Nat. Balear. 1976, 21, 115-124.

77. Nordsieck, F.; García-Talavera, F. Moluscos marinos de Canarias y Madera. (Gastropoda); Aula de Cultura de Tenerife: Madrid, Spain, 1979.

78. Gaffney, P.M. On the number of Patella species in south-west England. J. Mar. Biol. Assoc. UK 1980, 60, 565-574. [CrossRef]

79. Van Aartsen, J.J.; Menkhorst, H.P.M.G.; Gittenberger, E. The marine Mollusca of the Bay of Algeciras, Spain, with general notes on Mitrella, Marginellidae and Turridae. Basteria 1984, 2, 3-135.

80. Campbell, A.C. Country Life Guides. The Seashore and Shallow Seas of Britain and Europe; Country Life Books: Feltham, UK, 1985.

81. Backeljau, T. Lijst van de Recente Mariene Mollusken van België [A Checklist of the Recent Marine Molluscs of Belgium]; Documents; Koninklijk Belgisch Instituut voor Natuurwetenschappen: Brussels, Belgium, 1986.

82. Bosch, M.; Moreno, I. Contribución al conocimiento del género Patella Linné 1758, en la isla de Mallorca. Bolletí Soc. d'Història Nat. Balear. 1986, 30, 127-135.

83. Cervella, P.; Ramella, L.; Robotti, C.A.; Sella, G. Chromosome analysis of three species of Patella (Archaeogastropoda). Genetica 1988, 77, 97-103. [CrossRef]

84. Graham, A. Molluscs: Prosobranch and Pyramidellid Gastropods. Keys and Notes for the Identification of the Species; Kermack, D.M., Barnes, R.S.K., Eds.; The Linnean Society of London \& The Estuarine and Brackish-Water Sciences Association: Leiden, The Netherlands, 1988; ISBN 9004087710.

85. Lindner, G. Guide des Coquillages Marins, 2nd ed.; Delachaux et Niestlé, Neuchâtel: Paris, France, 1989 ; ISBN 2603006894.

86. Bellomo, E. Presenza di «Ospiti boreali» (Mollusca, Gastropoda) nel Pleistocene di Contrada Case Alte (Villa S. Giovanni). Boll. della Soc. Paleontol. Ital. 1993, 32, 393-399.

87. Weber, M. Aguda, Entre as Marés: Fauna e Flora do Litoral da Praia da Aguda; Edições Af.; Rainho \& Neves: Porto, Portugal, 1997; ISBN 9723604329.

88. Nakano, T.; Ozawa, T. Worldwide phylogeography of limpets of the order Patellogastropoda: Molecular, morphological and palaeontological evidence. J. Molluscan Stud. 2007, 73, 79-99. [CrossRef]

89. Santos, R.S.; Delgado, R.; Ferraz, R. Background Document for Azorean Limpet Patella aspera; OSPAR Commission: London, UK, 2010.

90. Castejón, D.; Cañizares, J.M.; Nogueira, N.; Andrade, C.A.P. Artificial maturation and larval production of the limpet Patella aspera Röding, 1798 (Patellogastropoda, Mollusca): Enhancing fertilization success of oocytes using NaOH-alkalinized seawater. Aquac. Res. 2021, 52, 1904-1914. [CrossRef]

91. Bean, W. A supplement of new species. In British Marine Conchology; Being a Descriptive Catalogue, Arranged According to the Lamarckian System, of the Salt Water Shells of Great Britain, by Charles Thorpe, Assisted by Several Distinguished Conchologists, and Illustrated with Numerous Delineation; Thorpe, C., Ed.; Edward Lumley: London, UK, 1844; pp. 263-267.

92. Forbes, E.; Hanley, S. A history of British Mollusca, and their Shells. In Including the Remaining Families of Bivalves, the Pteropoda, and the Gasteropoda as far as Ianthinidae; John Van Voorst: London, UK, 1853; Volume 2.

93. Dautzenberg, P. Une Excursion malacologique à Saint-Lunaire (Ille-et-Vilaine) et aux environs de cette localité. Bull. Société d'études Sci. Paris 1887, 9, 1-27.

94. Nobre, A. Moluscos Testáceos Marinhos do Arquipélago da Madeira; Coimbra University Press: Coimbra, Portugal, $1937 ;$ pp. 1-101.

95. Evans, R.G. Studies on the Biology of British limpets. Proc. Zool. Soc. Lond. 1947, 117, 411-423. [CrossRef]

96. Lucas, J.A.W. Het genus Patella in Nederland. Basteria 1954, 18, 36-40.

97. Nordsieck, F. Die Europäischen Meeres-Gehäuseschnecken (Prosobranchia): Vom Eismeer bis Kapverden, Mittelmeer und Schwarzes Meer; 2. Völlig; Fischer: Stuttgart, Germany, 1982; ISBN 3437303600.

98. Jay, J.C. A Catalogue of the Shells, Arranged According to the Lamarckian System: With Their Authorities, Synonymes, and References to Works Where Figured or Described: Together with a Supplement Containing Additional Species, Corrections, and Alterations/Contain; Craighead: New York, NY, USA, 1852.

99. Drouët, H. Mollusques Marins des Iles Açores; Baillière: Paris, France, 1858.

100. Payraudeau, B.C. Catalogue Descriptif et Méthodique des Annelides et des Mollusques de L'ile de Corse; Avec Huit Planches Représentant Quatre-Vingt-Huit Espéces, Dont Soixante-Huit Nouvelles; Béchet, Levrault, Paschoud, Treuttel et Wurtz: Paris, France, 1826.

101. Weinkauff, H.C. Systematisches Conchylien-Cabinet; Küster, H.C., Ed.; Bauer und Raspe: Nürnberg, Germany, 1880.

102. Anton, H.E. Verzeichniss der Conchylien: Welche sich in der Sammlung/von Hermann Eduard Anton befinden. Herausgegeben von dem Besitzer; E. Anton: Halle, Germany, 1838.

103. Di Monterosato, T.A. Molluschi del Porto de Palermo. Specie e varietà. Bull. della Soc. Malacol. Ital. 1888, 13, 161-180.

104. D'Orbigny, A. Mollusques, Echinodermes, Foraminifères et Polypiers recueillis aux Iles Canaries par MM. Webb et Berthelot. In Histoire naturelle des Iles Canaries; Barker-Webb, P., Berthelot, S., Eds.; Béthune: Paris, France, 1840; p. 117.

105. Lecointre, G.; Tinkler, K.J.; Richards, H.G. The marine Quaternary of the Canary Islands. In Proceedings of The Academy of Natural Sciences of Philadelphia; The Academy of Natural Sciences of Drexel University: Philadelphia, PA, USA, 1967; Volume 119, pp. 325-344.

106. Locard, A. Notices conchyliologiques. XXVIII. Description des deux coquilles marines nouvelles. L'Echange Rev. Linnéenne 1894, $10,131-132$. 
107. Milachewitch, K.O. Faune de la Russie et des Pays Limitrophes Fondée Principalement sur les Collections dur Musée Zoologique de l'Académie Impériale des Sciences de Petrograd. Les Mollusques de Mers Russes; Tome I. Le.: Petrograd, Russia, 1916.

108. Dunker, G. Index Molluscorum, Quae in Itinere ad Guineam Inferiorem Collegit Georgius Tams, Med. dr.; Accedunt Novarum Specierum Diagnoses, Cirripedia Nonnulla et X. Tabulae Iconum; Typis et sumptibus Theodori Fischer, Cassellis Cattorum: Kreisfreie, Germany, 1853. [CrossRef]

109. Mörch, O.A.L. Catalogus Conchyliorum Quae Reliquit D. Alphonso d'Aguirra \& Gadea Comes de Yoldi: Regis Daniae Cubiculariorum Princeps, Ordinis Dannebrogici in Prima Classe \& Ordinis Caroli Tertii Eques; Fasciculus; Ludovici Kleine: Hafniae, Denmark, 1852.

110. Meuschen, F.C. Museum Geversianum Sive Index Rerum Naturalium: Continens Instructissimam Copiam Pretiosissimorum Omnis Generis ex Tribus Regnis Naturae Objectorum: Quam Dum in Vivis Erat Magna Diligentia Multaque Cura Comparavit vir Amplissimus Abrahamus Gevers; P. \& J. Holsteyn Bibliopolas: Rotterdam, The Netherlands, 1787.

111. Salis Marschlins, C.U. von Reisen in verschiedene provinzen des Königreichs Neapel; Geografia; Ziegler \& Söhne: Zürich, Switzerland; Leipzig, Germany, 1793.

112. Delessert, B. Recueil de Coquilles Décrites par Lamarck Dans son Histoire Naturelle des Animaux sans Vertèbres et non Encore Figurées; Chez Fortin, Masson et Cie, Libraires: Paris, France, 1841.

113. Nordsieck, F. Conchiglie delle Isole Canarie. Parte 1: Patellae. La Conchiglia 1975, 73-74, 3-5.

114. Mabille, J. De quelques coquilles nouvelles. Bull. Soc. Philomath. Paris 1888, 12, 73-82.

115. Locard, A. Expéditions Scientifiques du Travailleur et du Talisman Pendant les Années 1880, 1881, 1882, 1883; Mollusques Testacés. Tome 2: Gastropoda; Milne-Edwards, A., Ed.; G. Masson: Paris, France, 1898.

116. Poppe, G.T.; Goto, Y. European seashells. Vol. 1. Polyplacophora, Caudofoveata, Solenogastra, Gastropoda; Verlag Christa Hemmen: Wiesbaden, Germany, 1991; ISBN 9783925919077.

117. Corte-Real, H.B.S.M.; Hawkins, S.J.; Thorpe, J.P. Genetic confirmation that intertidal and subtidal morphs of Patella ulyssiponensis aspera Röding (Mollusca: Gastropoda: Patellidae) are conspecific. Arquipélago-Life Earth Sci. 1992, 10, 55-66.

118. De Gregorio, A. Studi su talune conchiglie mediterranee viventi e fossili con una rivista del genere Vulsella. Bull. della Soc. Malacol. Ital. 1884, 10, 36-128.

119. Cabral, J.P. Concentrations of metals in Patella intermedia, Patella rustica, Patella ulyssiponensis and Patella vulgata shells along the Portuguese continental coast. Boll. Malacol. 2005, 41, 23-34.

120. Foslie, M. Algologiske notiser II. Det K. Nor. Vidensk. Selsk. Skr. 1906, 1906, 1-28.

121. Printz, H.M. Foslie: Contributions to a Monograph of the Lithothamnia; Kong. Norske Vidensk. Selsk. Mus.: Trondheim, Norway, 1929.

122. Adey, W.H.; Lebednik, P.A. Catalog of the Foslie Herbarium; Det Kongelige Norske Videnskabers Selskab Museet: Trondheim, Norway, 1967.

123. Woelkerling, W.J. Type collections of Corallinales (Rhodophyta) in the Foslie Herbarium (TRH). Gunneria 1993, $67,65$.

124. Irvine, L.M.; Chamberlain, Y.M. Seaweeds of the British Isles, 1 (2B). Corallinales, Hildenbrandiales; HMSO: London, UK, 1994; ISBN 0113100167.

125. Woelkerling, W.J.; Gustavsen, G.; Myklebost, H.E.; Prestø, T.; Såstad, S.M. The Coralline Red Algal Herbarium of Mikael Foslie: Revised Catalogue with Analyses; NTNU Vitenskapsmuseet: Trondheim, Norway, 2005; pp. 1-625.

126. Hall-Spencer, J.M.; Kelly, J.; Maggs, C.A. Background Document for Maërl Beds; OSPAR Commission: Paris, France, 2010.

127. Guiry, M.D. A Catalogue of Irish Seaweeds; A.R.G. Gantner Verlag K.G.: Ruggell, Liechtenstein, $2012 ;$ ISBN 9783905997101.

128. Hernandez-Kantun, J.J.; Rindi, F.; Adey, W.H.; Heesch, S.; Peña, V.; Le Gall, L.; Gabrielson, P.W. Sequencing type material resolves the identity and distribution of the generitype Lithophyllum incrustans, and related European species L. hibernicum and $L$. bathyporum (Corallinales, Rhodophyta). J. Phycol. 2015, 51, 791-807. [CrossRef]

129. Gallardo, T.; Bárbara, I.; Afonso-Carrillo, J.; Bermejo, R.; Altamirano, M.; Gómez Garreta, A.; Barceló Martí, M.C.; Rull Lluch, J.; Ballesteros, E.; De la Rosa, J. Nueva lista crítica de las algas bentónicas marinas de España [A new checklist of benthic marine algae of Spain]. Algas. Boletín Inf. la Soc. Española Ficología 2016, 51, 7-52.

130. Lugilde, J.; Peña, V.; Bárbara, I. The order Corallinales sensu lato (Rhodophyta) in the Iberian Atlantic: Current state of knowledge. An. Jardín Botánico Madr. 2016, 73, e038. [CrossRef]

131. Vázquez-Ferreira, R.; Peña, V. Type of sporangial division in Lithophyllum hibernicum (Corallinales, Rhodophyta) and implications on its life-history in Atlantic Europe [Tipo de división en esporocistes de Lithophyllum hibernicum (Corallinales, Rhodophyta) y su implicació. Nov. Acta Científica Compostel. 2016, 23, 99-106.

132. Cormaci, M.; Furnari, G.; Alongi, G. Marine benthic flora of the Mediterranean Sea: Rhodophyta (excluding Rhodymeniophycida) [Flora marina bentonica del Mediterraneo: Rhodophyta (Rhodymeniophycidae escluse)]. Bull. Gioenia Acad. Catania 2017, 50, FP1-FP391.

133. Hernandez-Kantun, J.J.; Hall-Spencer, J.M.; Grall, J.; Adey, W.; Rindi, F.; Maggs, C.A.; Bárbara, I.; Peña, V. North Atlantic rhodolith beds. In Rhodolith/Maërl Beds: A Global Perspective; Riosmena-Rodríguez, R., Nelson, W., Aguirre, J., Eds.; Springer International Publishing: Cham, Switzerland, 2017; pp. 265-279. ISBN 9783319293158.

134. Pardo, C.; Bárbara, I.; Barreiro, R.; Peña, V. Insights into species diversity of associated crustose coralline algae (Corallinophycidae, Rhodophyta) with Atlantic European maerl beds using DNA barcoding. An. Jardín Botánico Madr. 2017, 74, e059. [CrossRef]

135. Burel, T.; Duff, M.L.; Gall, E.A. Updated check-list of the seaweeds of the French coasts, Channel and Atlantic Ocean. Les Cah. Nat. l'Observatoire Mar. 2019, 7, 1-38. 
136. Athanasiadis, A. A study of the type material of Lithophyllum hibernicum (Lithophyllaceae, Corallinales, Rhodophyta) with comments on L. bathyporum and L. incrustans. Mar. Biol. Res. 2020, 16, 68-76. [CrossRef]

137. Foslie, M. On some Lithothamnia. Det K. Nor. Vidensk. Selsk. Skr. 1897, 1, 1-20.

138. Foslie, M. New or critical calcareous algae. Det K. Nor. Vidensk. Selsk. Skr. 1900, 5, 1-34.

139. Slatkin, M.; Hudson, R.R. Pairwise comparisons of mitochondrial DNA sequences in stable and exponentially growing populations. Genetics 1991, 129, 555-562. [CrossRef] [PubMed]

140. Sá-Pinto, A.; Branco, M.; Sayanda, D.; Alexandrino, P. Patterns of colonization, evolution and gene flow in species of the genus Patella in the Macaronesian Islands. Mol. Ecol. 2008, 17, 519-532. [CrossRef]

141. Sá-Pinto, A.; Branco, M.S.; Alexandrino, P.B.; Fontaine, M.C.; Baird, S.J.E. Barriers to Gene Flow in the Marine Environment: Insights from Two Common Intertidal Limpet Species of the Atlantic and Mediterranean. PLoS ONE 2012, 7, e50330. [CrossRef]

142. Sá-Pinto, A.; Branco, M.; Harris, D.J.; Alexandrino, P. Phylogeny and phylogeography of the genus Patella based on mitochondrial DNA sequence data. J. Exp. Mar. Bio. Ecol. 2005, 325, 95-110. [CrossRef]

143. Hedegaard, C.; Lindberg, D.R.; Bandel, K. Shell microstructure of a Triassic patellogastropod limpet. Lethaia 2000, 30, 331-335. [CrossRef]

144. Koufopanou, V.; Reid, D.G.; Ridgway, S.A.; Thomas, R.H. A Molecular Phylogeny of the Patellid Limpets (Gastropoda: Patellidae) and Its Implications for the Origins of Their Antitropical Distribution. Mol. Phylogenet. Evol. 1999, 11, 138-156. [CrossRef]

145. Crame, J.A. Bipolar molluscs and their evolutionary implications. J. Biogeogr. 1993, 20, 145-161. [CrossRef]

146. MolluscaBase (Ed.) MolluscaBase. Available online: https:/ / www.molluscabase.org/ (accessed on 28 October 2021).

147. Lozouet, P.; Maestrati, P. Nouvelles espèces de mollusques de l'Oligocène (Stampen) pour les bassins de Paris et d'Aquitaine. Arch. für Molluskenkd. 1982, 112, 165-189.

148. Lozouet, P. Nouvelles espèces de gastéropodes (Mollusca: Gastropoda) de l'Oligocène et du Miocène inférieur de l'Aquitaine (Sud-Ouest de la France). Cossmanniana 1999, 5, 61-102.

149. Landau, B.; Van Dingenen, F.; Ceulemans, L. The upper Miocene gastropods of northwestern France, 1. Patellogastropoda and Vetigastropoda. Cainozoic Res. 2017, 17, 75-166.

150. Martín-González, E.; Vera-Peláez, J.L.; Castillo, C.; Lozano-Francisco, M.C. New fossil gastropod species (Mollusca: Gastropoda) from the upper miocene of the canary islands (Spain). Zootaxa 2018, 4422, 191-218. [CrossRef] [PubMed]

151. Forli, M.; Dell'Angelo, B.; Montagna, P.; Taviani, M. A new large Patella in the Pliocene of the Mediterranean Sea.: (Mollusca: Patellogastropoda). Boll. Malacol. 2004, 40, 49-78.

152. Pacaud, J.M. Les espèces de mollusques du Danien décrites par Alcide d'Orbigny en 1850. In Stratotype Danien [Patrimoine Géologique Volume 9; Muséum National d’Histoire Naturelle: Paris, France, 2018; pp. 234-258.

153. Johnson, M.E.; Ledesma-Vázquez, J.; Ramalho, R.S.; da Silva, C.M.; Rebelo, A.C.; Santos, A.; Baarli, B.G.; Mayoral, E.; Cachão, M. Taphonomic range and sedimentary dynamics of modern and fossil rhodolith beds: Macaronesian realm (North Atlantic Ocean). In Rhodolith/Maërl Beds: A Global Perspective; Riosmena-Rodríguez, R., Nelson, W., Aguirre, J., Eds.; Springer International Publishing: Cham, Switzerland, 2017; ISBN 978-3-319-29313-4.

154. Johnson, M.E.; da Silva, C.M.; Santos, A.; Baarli, B.G.; Cachão, M.; Mayoral, E.J.; Rebelo, A.C.; Ledesma-Vázquez, J. Rhodolith transport and immobilization on a volcanically active rocky shore: Middle Miocene at Cabeço das Laranjas on Ilhéu de Cima (Madeira Archipelago, Portugal). Palaeogeogr. Palaeoclimatol. Palaeoecol. 2011, 300, 113-127. [CrossRef]

155. Ribeiro, P.A. Dispersal and Connectivity of Northeastern Atlantic Patellid Limpets: A Multidisciplinary Approach. Ph.D. Thesis, University of Southampton, Southampton, UK, 2008.

156. Frizon de Lamotte, D.; Fourdan, B.; Leleu, S.; Leparmentier, F.; de Clarens, P. Style of rifting and the stages of Pangea breakup. Tectonics 2015, 34, 1009-1029. [CrossRef]

157. Müller, R.D.; Seton, M.; Zahirovic, S.; Williams, S.E.; Matthews, K.J.; Wright, N.M.; Shephard, G.E.; Maloney, K.T.; Barnett-Moore, N.; Hosseinpour, M.; et al. Ocean Basin Evolution and Global-Scale Plate Reorganization Events Since Pangea Breakup. Annu. Rev. Earth Planet. Sci. 2016, 44, 107-138. [CrossRef]

158. Barnett-Moore, N.; Müller, D.R.; Williams, S.; Skogseid, J.; Seton, M. A reconstruction of the North Atlantic since the earliest Jurassic. Basin Res. 2018, 30, 160-185. [CrossRef]

159. Torsvik, T.H.; Cocks, L.R.M. Earth History and Palaeogeography; Cambridge University Press: Cambridge, UK, 2017; ISBN 9781316225523.

160. Fernández-Palacios, J.M.; de Nascimento, L.; Otto, R.; Delgado, J.D.; García-del-Rey, E.; Arévalo, J.R.; Whittaker, R.J. A reconstruction of Palaeo-Macaronesia, with particular reference to the long-term biogeography of the Atlantic island laurel forests. J. Biogeogr. 2011, 38, 226-246. [CrossRef]

161. Mitchell-Thomé, R.C. Radiometric studies in Macaronesia. Bol. Mus. Munic. Funchal 1985, 37, 52-85.

162. De Favanne de Montcervelle, M. La Conchyliologie, Ou, Histoire Naturelle des Coquilles de Mer, D'eau Douce, Terrestres et Fossiles: Avec un Traité de la Zoomorphose, ou, Représentation des Animaux qui les Habitent, Ouvrage Dans Lequel on Trouve Une nouvelle Méthode de les Diviser/Par; Desallier D’Argenville, M., Ed.; Chez Guillaume De Bure Fils Aîné: Paris, France, 1780.

163. MolluscaBase Patella aspera Lamarck. 1819. Available online: http:/ / www.marinespecies.org/aphia.php?p=taxdetails\&id=146455 (accessed on 25 March 2021).

164. Costa, D.A.; Christoffersen, M.L. New status for hesionid polychaetes (Annelida, Polychaeta). Gaia Sci. 2016, 10, 160-165. [CrossRef] 
165. International Commission on Zoological Nomenclature International Code of Zoological Nomenclature. Available online: https:/ / code.iczn.org/criteria-of-publication/article-8-what-constitutes-published-work/?frame=1 (accessed on 25 March 2021).

166. Smith, S.M.; Heppell, D. Checklist of British Marine Mollusca; Trustees of the National Museums of Scotland: Edinburgh, UK, 1991.

167. Sella, G.; Robotti, C.A.; Biglione, V. Genetic divergence among three sympatric species of Mediterranean Patella (Archaeogastropoda). Mar. Biol. 1993, 115, 401-405. [CrossRef]

168. Mauro, A.; Arculeo, M.; Parrinello, N. Morphological and molecular tools in identifying the Mediterranean limpets Patella caerulea, Patella aspera and Patella rustica. J. Exp. Mar. Bio. Ecol. 2003, 295, 131-143. [CrossRef]

169. Arguelles, E.D.L.R. First taxonomic records of epizoic freshwater algae on golden apple snails (Pomacea canaliculata Lamarck) from rice paddies in Laguna (Philippines). Philipp. J. Sci. 2021, 150, 829-844.

170. Harvey, A.; Johnson, M.E.; Harvey, R. Heterozoan carbonate-enriched beach sand and coastal dunes-with particular reference to rhodoliths, Dirk Hartog Island, Shark Bay, Western Australia. Facies 2018, 64, 23. [CrossRef]

171. Farr, T.; Broom, J.; Hart, D.; Neill, K.; Nelson, W. Common Coralline Algae of Northern New Zealand: An. Identification Guide; NIWA: Auckland, New Zealand, 2009; ISBN 1174-264X.

172. Harvey, A.; William, W.; Far, T.; Neill, K.; Nelson, W. Coralline Algae of Central New Zealand An Identification Guide to Common 'Crustose' Species Coralline Algae of Central New Zealand; NIWA: Auckland, New Zealand, 2005.

173. Woelkerling, W.J. A taxonomic reassessment of Lithophyllum (Corallinaceae, Rhodophyta) based on studies of R. A. Philippi's original collections. Br. Phycol. J. 1983, 18, 299-327. [CrossRef]

174. Barrientos, S.; Barreiro, R.; Olmedo, M.; Piñeiro-Corbeira, C. Can patch size and patch distance improve the recolonization of mussel-seed beds exploited for aquaculture? Aquat. Conserv. Mar. Freshw. Ecosyst. 2019, 29, 1897-1908. [CrossRef]

175. Johnson, M.E.; Baarli, B.G.; Cachão, M.; da Silva, C.M.; Ledesma-Vázquez, J.; Mayoral, E.J.; Ramalho, R.S.; Santos, A. Rhodoliths, uniformitarianism, and Darwin: Pleistocene and Recent carbonate deposits in the Cape Verde and Canary archipelagos. Palaeogeogr. Palaeoclimatol. Palaeoecol. 2012, 329-330, 83-100. [CrossRef]

176. Darwin, C. Geological Observations on the Volcanic Islands and Parts of South America Visited during the Voyage of H.M.S. "Beagle", 3rd ed.; Appleton and Company: New York, NY, USA, 1891. 